\title{
8. METASOMATIC AND METAMORPHIC PECULIARITIES OF THE DIABASE DIKE ALTERATION IN HOLE 504B, LEG 140'
}

\author{
Nikolai N. Pertsev² and Eugenii B. Kurdyukov²
}

\begin{abstract}
The diabase dikes recovered during Leg 140 display four types of mineralogical alteration: (1) chlorite + amphibole + titanite; (2) chlorite + amphibole + ilmenite; (3) epidote + prehnite + anhydrite; (4) zeolites + smectite. The first two types represent both background and vein alteration. The third and fourth types are locally overprinted on the previous types. The third type exhibits oxidative features, whereas the fourth formed with cooling of the dike complex. Some veins and patches of strong alteration are surrounded by infiltrate-metasomatic halos, which suggest a difference in fluid pressure in pores and fractures. The temperature of the main alteration types ranged between $350^{\circ}$ and $400^{\circ} \mathrm{C}$. Noticeable temperature fluctuations in space and time were caused by alternating heating and cooling resulting from intrusions of younger dikes within short time intervals.
\end{abstract}

\section{INTRODUCTION}

Hole 504B is the deepest oceanic borehole and the only one that has nearly penetrated the entire second layer of the oceanic crust. The hole has provided a unique opportunity to examine secondary alteration of basites in the oceanic environment over a considerable range of depths.

Since the hole was begun in 1979 , secondary alteration has been studied by many researchers (Adamson, 1983; Alt et al., 1983, 1985, 1986; Honnorez et al., 1983; Kurnosov et al., 1983; Laverne, 1983; Noack et al., 1983; Pertsev and Boronikhin, 1983a, 1983b; Ishizuka, 1989; Bohlke, 1980; Hart, 1973; Mével, 1980). Their data were used, along with data from other deep-penetration holes in the oceanic basement (Bass, 1976; Pertsev and Rusinov, 1980; etc.), as a basis for this study. The chief results of the preexisting studies are summarized as follows:

1. The younger (5.9 Ma, Hole 504B) and the older (e.g., $109 \mathrm{Ma}$, Hole 417D on the Bermuda Slope) basalts are identical in both the character and intensity of secondary alteration, which points to a considerable rate and short-lived character of these types of alteration.

2. Two general and ubiquitous types of secondary alteration are observed. The first type, which we provisionally call background and reductive, occurs ubiquitously with different intensity depending on the grain size of rocks, the presence of cracks, and some other causes. This type does not show considerable oxidizing features. The second, oxidative, type occurs far more locally, commonly in or near veinlets, and seems to be overprinted on the background alteration because of the introduction of fresh seawater along cracks and tectonic disruptions. This is confirmed by the increase in frequency and intensity of this type of alteration toward the surface of the oceanic basement (Pertsev and Rusinov, 1980).

3. In the basement sequence, the temperature of alteration generally increases with depth. In the upper portion of the basement, in pillow lavas and flows, these types of alteration result mainly in the formation of clay minerals (smectites in the back-

'Alt, J.C., Kinoshita, H., Stokking, L. B., and Michael, P.J. (Eds.), 1996. Proc. ODP. Sci. Results, 148: College Station, TX (Ocean Drilling Program).

${ }^{2}$ Institute of Geology of Ore Deposits, Petrography, Mineralogy and Geochemistry, Russian Academy of Sciences, Moscow, 109017, Russia. Pertsev, Kurdyukov: Pertsev@igem.msk.su ground alteration and celadonites in oxidative alteration). Other ubiquitous minerals are calcite and, in oxidized environments, also alkalic zeolites and adularia (Pertsev and Boronikhin, 1983a, 1983b). The upper portion of the sequence is devoid of higher-temperature minerals, with the exception of rare occurrences of such rather high-temperature minerals as melanite and aegirine-augite (Laverne, 1983), which crystallized during the cooling of thick basalt flows. With increasing depth, mixed-layer silicates (talc-smectite and chlorite-smectite), anhydrite, Ca-zeolites, and then albite, chlorite, talc, serpentine and amphibole (generally actinolite and actinolitic hornblende) are observed (Alt et al., 1985; Ishizuka, 1989).

4. A fairly small percentage of numerous veins of secondary minerals is accompanied by wall-rock alteration. These zones are commonly referred to as halos. These halos were found to be produced by infiltration metasomatism (Pertsev and Boronikhin, 1983a, 1983b), that is, their occurrence is caused by a flow of solutions away from cracks.

The present study is based on a limited sample suite obtained during Leg 140 by one of the authors (NP), including core samples and thin sections examined during Leg 140 as well as the data from structural-petrological and geochemical studies performed by the Leg 140 Shipboard Scientific Party (including the distinction of petrographic units, geochemical descriptions, etc.; Dick, Erzinger, Stokking, et al., 1992). Some of our results confirm those of previous investigators, whereas other results disagree or are inconsistent with other results and interpretations. We have no intention of presenting a comprehensive description of basite alteration in Hole 504B. This is prevented by the relative scarcity of the material available and our analytical capabilities. Our objective was to determine the patterns and relationships of the chief types of secondary alteration, structure and genesis of metasomatic veins, and the evolution of the alteration processes in the lower portion of the sheeted complex in Hole 504B.

\section{STRUCTURE OF THE DIKE COMPLEX}

To reveal possible interrelations between types of secondary alteration and the sequence of dike intrusions, we tried, where possible, to determine the relative ages of petrographic units (dikes). New dikes are typically emplaced by filling in a fracture in a preexisting dike in the sheeted complex. In this process, the older dike is broken into two portions with quench rims on opposite sides, forming a dike- 
in-dike structure. In this study, we refer to the half-dike with a single quench rim as a semidike. Another common mode of dike emplacement occurs when a new dike intrudes along the contact between two older dikes, in which case both the older dikes are preserved. Unfortunately, poor core recovery did not permit us to reconstruct a comprehensive picture of the sequence of dike emplacement. In addition to considering dikes detected on the basis of quench rims (Dick, Erzinger, Stokking, et al., 1992), we attempted by macroscopic and microscopic examination of the core also to consider changes of grain dimension. Although this approach may be somewhat arbitrary because entire units may have been missed because of poor core recovery, we think that this approach revealed a more plausible overall scheme of dike intrusions than could be reconstructed solely on the basis of quench rims. The results are presented in Figure 1, in which the material recovered from the hole is subdivided into a number of units with more or less clear age relationships between dikes and semidikes, as indicated by inferred chilled dike margins in Figure 1.

As evident from the schematic column and inferred relative dike ages in Figure 1, the most common type of alteration in the core recovered is amphibole-chlorite (with amphibole dominating over chlorite), whereas anhydrite-prehnite-epidote mineralization occurs far more rarely and is chiefly restricted to younger dikes (Units 218 , $220,221,244,245,255$, and 256) or to older units (e.g., Units 243 and 254), which occur near younger units.

In summary, the character of diabase alteration is generally uniform throughout the lower dike interval penetrated during Leg 140. The main secondary minerals are chlorite and amphibole, with occasional occurrences of the epidote-prehnite-anhydrite assemblage in patches and veinlets related to younger dikes.

\section{METHODS}

Microprobe analyses of minerals were performed using a Cameca MS-46 electron microprobe at IGEM, Russian Academy Sciences (Moscow) at $15 \mathrm{kV}$. The primary (magmatic) minerals are olivine, clinopyroxene, basic plagioclase, titanomagnetite, and spinel. The secondary minerals include amphibole, chlorite, talc, magnetite, ilmenite, sodic plagioclase, smectite, and titanite. The following standards were used for microprobe analyses: diopside for $\mathrm{Mg}, \mathrm{Ca}$, and $\mathrm{Fe}$ in silicates; hornblende for $\mathrm{Al}$ in augite and other silicates; fayalite for $\mathrm{Fe}$ and $\mathrm{Si}$; aegirine for $\mathrm{Na}$; sanidine for $\mathrm{Si}, \mathrm{K}$, and $\mathrm{Al}$; chromite for $\mathrm{Cr}$; rutile for $\mathrm{Ti}$; and scapolite for $\mathrm{Cl}$.

\section{MINERAL PARAGENESES AND MORPHOLOGIC FEATURES OF DIABASE DIKE ALTERATION}

Three forms of alteration development are considered (Dick, Erzinger, Stokking, et al., 1992): background, more or less uniform alteration throughout the rock; patches of secondary minerals; and veins composed of secondary minerals. A fourth form is pseudomorphs after olivine phenocrysts and commonly consists of specific sets of minerals. The first three types of alteration can be divided into four paragenetic groups:

1. chlorite + amphibole + titanite \pm (albite, quartz);

2. chlorite + amphibole + ilmenite + (albite, quartz);

3. epidote + prehnite + anhydrite + (chlorite, amphibole, quartz, albite);

4. zeolites + clay minerals.

The first and the second paragenetic groups make up the background, patch, and vein forms of alteration. The distinction between these groups lies in titanium minerals. Groups 3 and 4 appear to be younger, and overprint chlorite-amphibole background alteration both in veins and as disseminated grains. They are distributed locally and, in general, manifest themselves in minor amounts.

\section{BACKGROUND ALTERATION OF PARAGENETIC GROUPS 1 AND 2}

The two predominant minerals in altered patches are chlorite and amphibole. Both minerals replace partly or completely the interstitial groundmass, which consisted originally of olivine, augite, plagioclase, and titanomagnetite. Where the alteration is intense enough, larger grains and phenocrysts of plagioclase and clinopyroxene display replacement by chlorite and/or amphibole in grain edges. Both chlorite and amphibole in the groundmass are fine grained, randomly oriented, and commonly felt-like. Larger chlorite grains (with or without inclusions of amphibole fibers) appear to be pseudomorphs after olivine grains. Chlorite-amphibole background alteration is accompanied usually by minor albite, quartz, sulfides (mostly pyrite), and titanite or ilmenite. Ilmenite appears to occur at higher amphibole/chlorite ratio. Although amphibole is generally predominant, the amount of essential chlorite may have been underestimated because of low recovery from depth intervals enriched in chlorite.

\section{VEINS OF THE MAIN PARAGENETIC GROUPS}

Fine veins cut diabase dikes at angles ranging from steep to gentle. The veins are usually monomineralic in composition (chlorite or amphibole). If both minerals are present in a vein, the vein exhibits zonation in which chlorite is in the outer parts and amphibole constitutes the center of the vein. This seems to be confirmed by the observation that the minerals in a vein are oriented independently of the grains of respective minerals in the crack wall and on the secondary filling of veins that formed when the veins reopened. Commonly, the reopening of an old vein occurs along one of its walls and new veinfilling material (chlorite or amphibole of different color and composition) may cut an older filling of the vein and switch from one to the other wall of the vein.

The statistical measurements performed on board have shown that the frequency of chlorite veins cutting amphibole veins is almost equal to the frequency at which amphibole veins cut chlorite veins (Dick, Erzinger, Stokking, et al., 1992). Where several veins crosscut, some of chlorite veins are younger and some are older than amphibole veins.

The veins may or may not have metasomatic near-vein zonation ("halo"). Veins without halos occur much more commonly than those with halos. The thickness of the veins without halos is generally less than $1 \mathrm{~mm}$. These veins occur in all petrographic units and generally consist of chlorite or amphibole, or, more rarely, both. Chlorite + amphibole veins without halos are interpreted as veins of filling, and refilling, where fractures have reopened the veins (i.e., the veins originated in at least two stages).

Veins with halos are usually up to $2 \mathrm{~mm}$ thicker than veins without halos, and are bordered by halos up to several millimeters thick (Fig. 2). The veins are composed of amphibole and the halos contain amphibole, or chlorite, or both. The lighter or darker gray color of halos depends on the host rock and differs from vein to vein. The contacts of near-vein zones are sharp.

The minerals from three typical samples of metasomatic zones (halos) were analyzed using the electron microprobe. Sample 140504B-198R-1, 66-68 cm (Piece 17), Unit 223, represents weakly altered diabase with preserved skeletal titanomagnetite, chlorite developing in interstitial groundmass, and sparse amphibole rims along augite grain borders. The rock is cut by a vein about $1 \mathrm{~mm}$ in thickness. The vein contains brownish coarsely crystalline amphibole of random orientation. The amphibole in the vein (actinolitic horn- 
blende) is discolored along hair-line veins that either follow a contact of the main vein or are situated within the main vein. The amphibole discoloration seems to be caused by later processes of vein reopening. Symmetrical near-vein zones, about $2 \mathrm{~mm}$ wide along at each side of the vein, consist of nearly equal volumes of brownish amphibole, light-green chlorite, and relict plagioclase, with accessory ilmenite. Neither titanomagnetite (magnetite) or titanite are present. The zones have sharp contacts with both the vein and host rocks.

Amphibole compositions in the vein, halo, and host rock of one sample are shown in Figure 3. Hornblende outside the halo has higher contents of $\mathrm{TiO}_{2}(0.22 \%), \mathrm{Al}_{2} \mathrm{O}_{3}(7.01 \%), \mathrm{MgO}(16.60 \%), \mathrm{Na}_{2} \mathrm{O}$ $(0.62 \%), \mathrm{Cr}_{2} \mathrm{O}_{3}(0.12 \%)$, and lower amounts of $\mathrm{CaO}(8.48 \%)$ and $\mathrm{FeO}_{\text {tot }}(14.66 \%)$. Brownish amphiboles from the vein and near-vein zones are different in composition (Fig. 3). The compositional trends of minerals from veins and halos and especially sharp changes in composition at the borders of the zones suggest an infiltrate-metasomatic origin for the latter rather than diffusion if equilibrium prevailed during alteration (Korzhinskii, 1970). Because the amphiboles occupy a larger volume in metasomatic halos than in the host rock, they contain less immobile components, such as $\mathrm{TiO}_{2}, \mathrm{Al}_{2} \mathrm{O}_{3}$, and $\mathrm{Cr}_{2} \mathrm{O}_{3}$.

The second sample studied (Sample 140-504B-198R-1, 70-72 $\mathrm{cm}$, Piece 18) was collected near the first one but from underlying Unit 224. The sample represents strongly altered diabase with plagioclase and rare relics of augite as the only surviving magmatic minerals. The dominant secondary mineral is brownish amphibole, whereas chlorite is scarce and seems to be strongly confined within olivine grains. The amphibole vein (about $2 \mathrm{~mm}$ across) has symmetrical, 6-mm-thick alteration halos along each side. In contrast to the surrounding rocks, these halos have a lighter color and are mainly composed of relict plagioclase (about $50 \%$ ), chlorite (about $35 \%$ ), amphibole (about 15\%), and minor titanite and pyrite. Several thinner amphibole-chlorite veinlets cut both the main vein and its halo. Compositions of minerals from the vein and halos are shown in Figure 4. Light-brown amphiboles from the vein are compositionally different from the brown amphiboles of halos: the vein amphiboles have lower contents of $\mathrm{TiO}_{2}(0.02-0.03$ vs. $0.05 \%-0.17 \%$ in the vein and halo, respectively), lower $\mathrm{Al}_{2} \mathrm{O}_{3}$ (3.03.4 vs. $5.79 .3 \%$ ), and higher $\mathrm{FeO}_{\text {tot }}$ (13.6-15.2 vs. $10.8-12.6 \%)$. As in the first sample, this zonation has sharp changes in the main components, characteristic of an infiltration-metasomatic origin, assuming equilibrium.

The last sample (140-504B-208R-1, 85-87 cm, Piece 19A, Unit 239; Fig. 2) represents moderately altered diabase with only partially altered magmatic plagioclase, augite, and titanomagnetite. The main secondary mineral is amphibole, and rare round chlorite grains appear to replace olivine. Minor titanite forms aggregates of skeletal grains near partly altered magmatic titanomagnetite. A 1- to 4-mm amphibole vein with 4 - to 6-mm halos along each side cuts the sample. The near-vein zones have sharp contacts and consist of amphibole replacing augite almost completely. Relict plagioclase is partly replaced by albite. Amphibole is more abundant than chlorite, which occurs mainly near the vein. The amphiboles from the monomineralic vein and the near-vein halos are almost equal in composition (Fig. 5). The most distinguishing difference is the $\mathrm{TiO}_{2}$ content; less pronounced are the differences in $\mathrm{CaO}, \mathrm{Al}_{2} \mathrm{O}_{3}$, and $\mathrm{Na}_{2} \mathrm{O}$ contents. The sharp compositional changes at the borders between the halos and host rock suggest that diffusional transport of main components was absent or suppressed and that, if equilibrium prevailed, the infiltration mechanism was predominant in this metasomatic system.

The patches of strong alteration exhibit irregular outlines on the split surface of the core (Fig. 6), and appear to produce a very complicated pipe-like morphology in three-dimensional space. In the core, the patches are not large, only up to several centimeters across, and consist completely of secondary minerals, mostly felt-like amphibole with subordinate fine chlorite and minor titanite or ilmenite, and sulfides (pyrite mainly). Like the zoned metasomatic veins, the patches are surrounded by a zone (up to $1 \mathrm{~cm}$ across) rich in amphibole and bearing many plagioclase relics. The host rock is much less altered. The intermediate halo (zone) forms contacts distinct on both sides and displays constant mineral composition, suggesting a similarity with metasomatic veins having halos. Moreover, the patches are located usually in the intervals where metasomatic zonal veins occur. Thus, it is highly possible that the patches are formed along pipelike complex paths of preferred permeability contemporary with the metasomatic veins which formed along fractures.

\section{MINERAL CHEMISTRIES}

Olivine (Table 1) is the least resistant mineral to any alteration. Interstitial olivine in the groundmass is not preserved. The mineral occurs as euhedral grains up to several millimeters across that usually are replaced almost completely by chlorite with small quartz crystals surrounded by serpentine and/or talc with magnetite dust, fine sulfide or mix-layered talc-smectites. Relics of unaltered olivine phenocrysts are rare. The fresh olivine relics have a high magnesian content $(\mathrm{X}[\mathrm{Mg}]=0.87-0.88)$.

High-temperature Ca-free amphiboles, anthophyllite, and cummingtonite, were found as constituents of pseudomorphs after olivine in the middle part of the dike complex, Hole 504B, Leg 111 (Ishizuka, 1989). A peculiar feature of the olivine pseudomorphs in the sheeted diabase dikes (in contrast to those in the superjacent basalts) is an independence of their mineral composition on background alteration. Assemblages of the latter are formed at a rather uniform temperature, whereas the olivine pseudomorphs commonly display assemblages of somewhat higher and/or lower temperatures and other chemical conditions.

Clinopyroxene (Table 2) is one of the least altered magmatic minerals. Secondary chlorite and amphibole are commonly restricted to fractures or interstitial areas. The clinopyroxene generally forms subhedral phenocrysts of pale-green or pinkish green color with a very light pleochroism. Chemically, clinopyroxenes can be divided into two groups: one with $\mathrm{X}(\mathrm{Mg})=0.82-0.86$ and high $\mathrm{TiO}_{2}$ and $\mathrm{Cr}_{2} \mathrm{O}_{3}$ contents (up to $0.5 \mathrm{wt} \%$ each), and another with $\mathrm{X}(\mathrm{Mg})=0.62-0.67$, somewhat lower $\mathrm{TiO}_{2}$ and low $\mathrm{Cr}_{2} \mathrm{O}_{3}$ (usually about 0 ). In addition, several pyroxenes have intermediate values of $\mathrm{X}(\mathrm{Mg})$ and $\mathrm{Cr}_{2} \mathrm{O}_{3}$ and $\mathrm{TiO}_{2}$ percentages. Pyroxenes of the first group seem to correspond to xenocrysts, whereas those of the second group are either phenocrysts or groundmass.

Primary magmatic plagioclase forms both phenocrysts and groundmass in the rocks and corresponds to labradorite to bytownite $(\mathrm{X}[\mathrm{Ca}]=0.74-0.87$; Table 3$)$. Two predominant secondary minerals replacing the plagioclase are chlorite and sodium-rich plagioclase. The latter forms hair-thick veins within magmatic plagioclase and is present in fine-grained secondary groundmass. Secondary plagioclase is mainly albite, although many grains intermediate between magmatic and metamorphic plagioclases $(\mathrm{X}[\mathrm{Ca}]=0.10-0.32)$ were found by means of the microprobe.

Primary magnetite (Table 4) differs from secondary in $\mathrm{TiO}_{2}$ content (up to $28 \mathrm{wt} \%$ in the former and less than $3 \mathrm{wt} \%$ in the latter). Ilmenite was found unexpectedly during microprobe examination of the rocks. The ilmenite occurs as scarce scattered grains in rather intensely altered diabase, which contains no magmatic titanomagnetite. Titanomagnetite is commonly very sensitive to greenstone alteration and is among the first minerals to decompose in this process to provide iron to chlorite and amphibole and titanium to titanite. In the ilmenite occurrences mentioned, no titanite rim or scattered titanite grains were observed in the vicinity of the titanomagnetite (as is commonly the case in moderately altered diabases). The absence of primary titanomagnetite and secondary titanite suggests that this ilmenite is a secondary mineral formed at the expense of titanomagnetite. Representative ilmenite analyses are listed in Table 5. Low to 
Figure 1. Structural position and alteration features of samples of sheeted dike diabases recovered during Leg 140. $\mathrm{Am} /(\mathrm{Am}+\mathrm{Chl})=$ approximate volumetric amphibole fraction in chlorite-amphibole assemblage. Amphibole type: $\mathrm{A}=$ actinolite, $\mathrm{H}=$ hornblende, $\mathrm{AH}=$ actinolitic hornblende, mole fraction $\mathrm{X}(\mathrm{Mg})=\mathrm{Mg}$ / $(\mathrm{Mg}+\mathrm{Fe})$. Chlorite type: $\mathrm{D}=$ diabantite, $\mathrm{P}=$ pycnochlorite, $\mathrm{R}=$ ripidolite, mole fraction $\mathrm{X}(\mathrm{Mg})=\mathrm{Mg} /$

$(\mathrm{Mg}+\mathrm{Fe})$. Plagioclase composition: Plag. mole fraction $\mathrm{X}(\mathrm{Ca})=$ anorthite mole fraction. Veins with halos $=$ places where halos were observed adjacent to veins and patches. Titan. miner. $=$ places where ilmenite $(\mathrm{I})$ was observed. EAP = alteration assemblage epidote + anhydrite + prehnite. Structural features Inferred chilled dike margins are indicated by hachures, providing relative age relationships among dikes (see text).

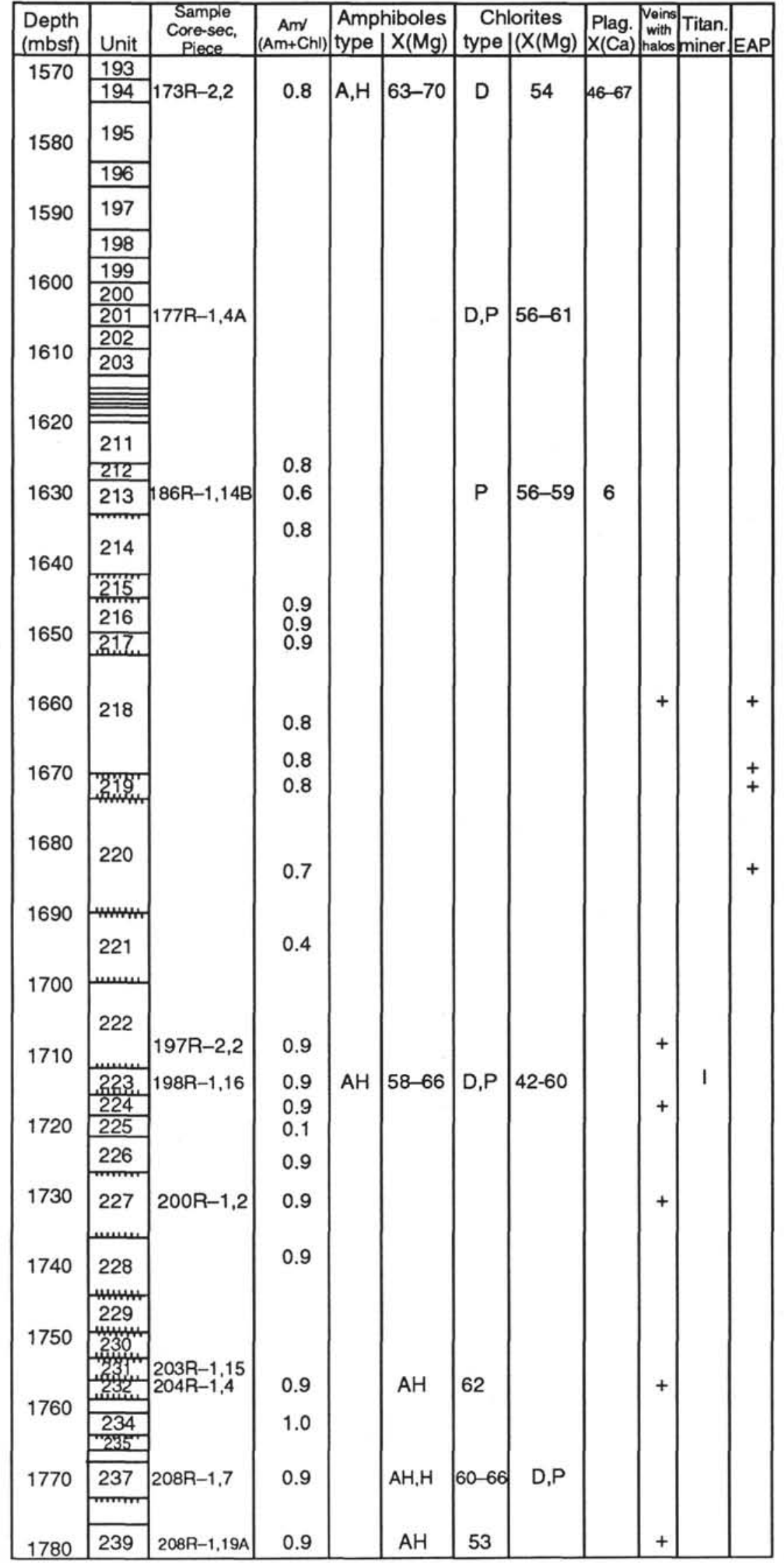




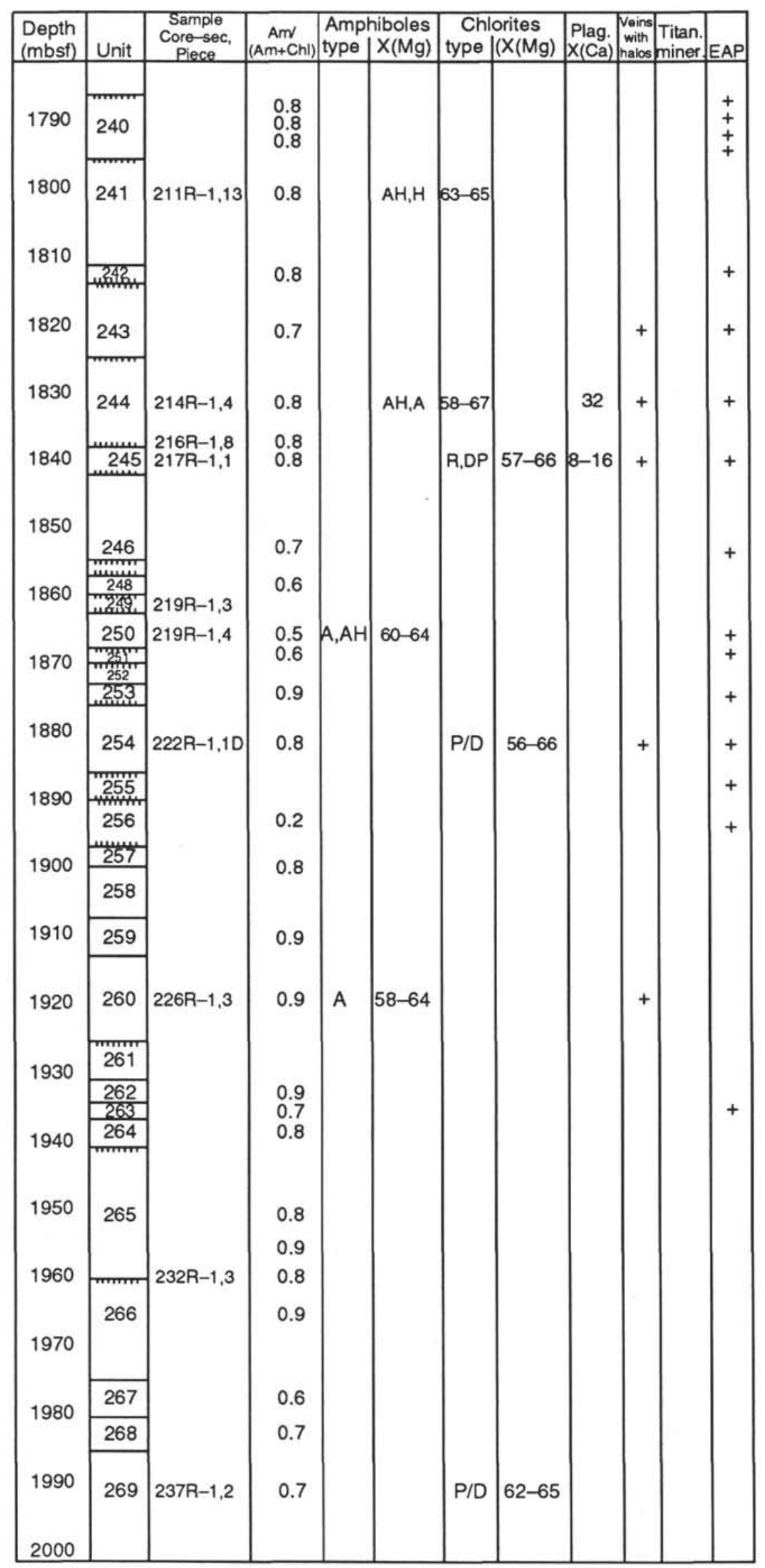

Figure I (continued). 


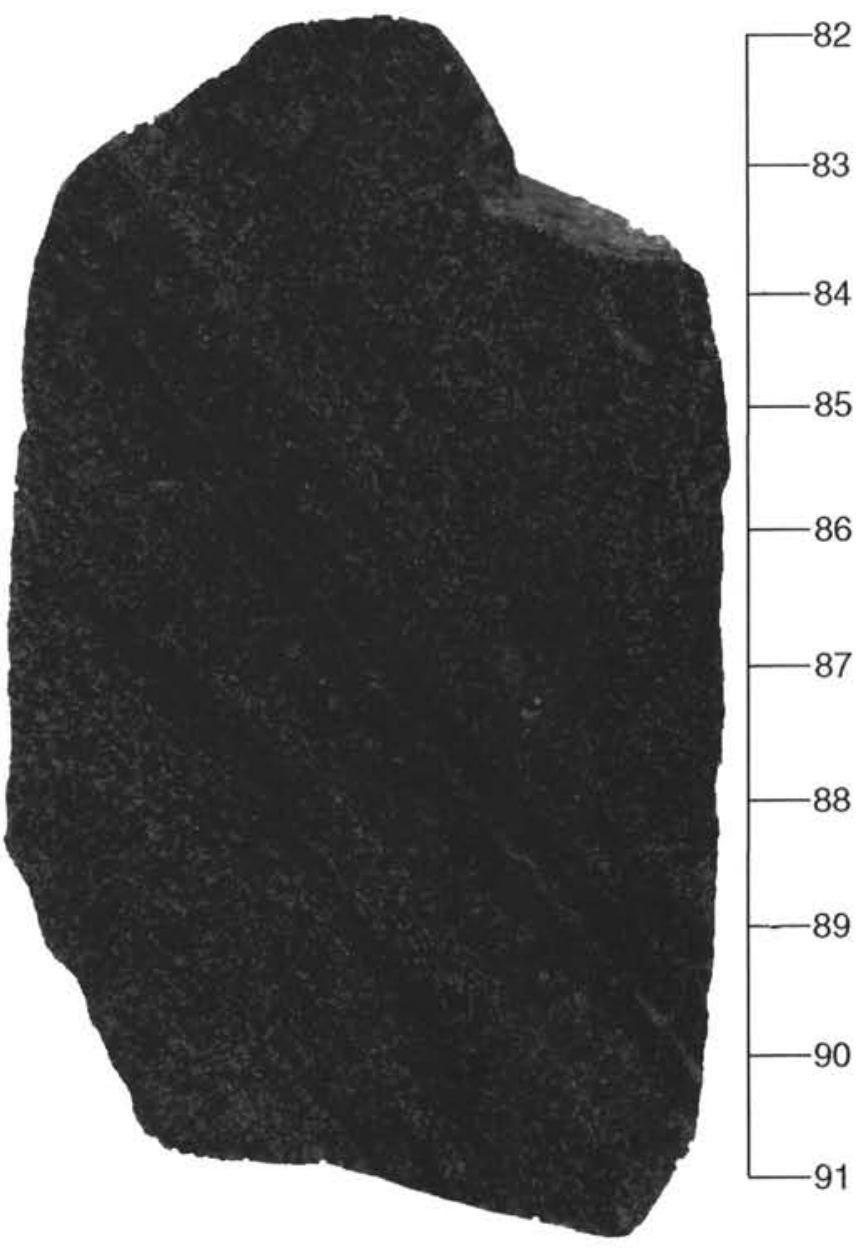

Figure 2. Photomicrograph of a vein in Sample 140-504B-208R-1, 82-91 cm (Piece 19A). The vein is composed of light actinolitic hornblende and is surrounded by symmetric zones (halos) of darker amphibole.

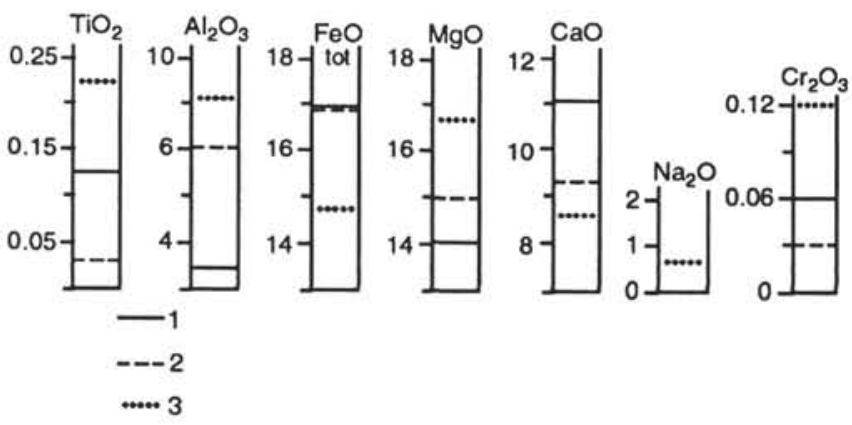

Figure 3. Contents of some characteristic components in metasomatic zonation of Sample 140-504B-198R-1,66-68 cm (Piece 17), Unit 223. 1 = discolored actinolite from an amphibole vein; 2 = brown actinolitic hornblende from an amphibole vein and near-vein zone (halo): 3 = actinolitic hornblende from rims around augite in host rock.

negligible $\mathrm{CaO}$ contents bear witness to the insignificance of admixed titanite.

Spinel (Table 4) occurs only as an accessory magmatic mineral. It is euhedral, and usually is included in phenocrysts of other minerals. $\mathrm{Cr}_{2} \mathrm{O}_{3}$ content varies from 27 to 36.5 wt \% (see Table 5).

Amphibole (Table 6; Fig. 7) occurs in altered rocks as long-prismatic or needle-shaped single crystals, patches of fine-grained

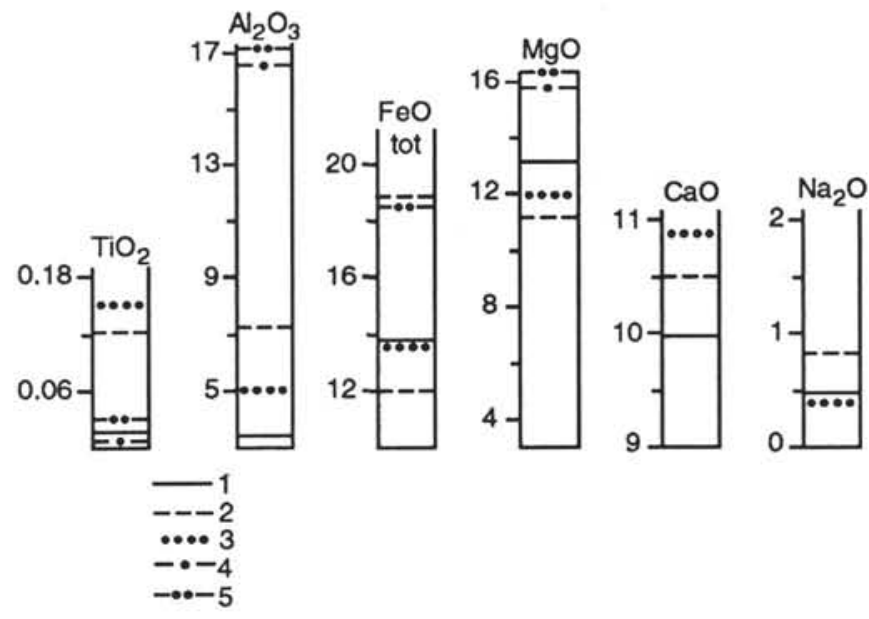

Figure 4. Contents of some characteristic components in secondary minerals from the metasomatic zonation in Sample 140-504B-198R-1, 70-72 cm (Piece 18), Unit 224. 1 = light-brown actinolite from a monomineralic vein; 2 = brown actinolitic hornblende from the halo; 3 = fine-grained actinolite with some admixed chlorite derived from the later vein which cut the earlier haloed vein; 4 = chlorite from the halo; 5 = fine-grained chlorite with some amphibole from the host rock.

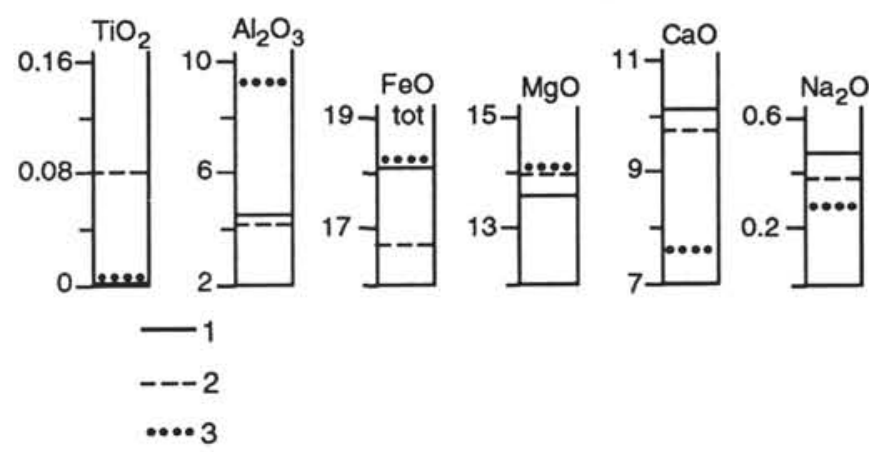

Figure 5. Contents of some characteristic components in secondary minerals from the metasomatic zonation in Sample 140-504B-208R-1, 85-87 cm (Piece 19A), Unit 239. 1 = actinolitic hornblende from a monomineralic vein; 2 = actinolitic hornblende from the near-vein zone; 3 = fine-grained actinolite with some chlorite mixed in from the host rock.

amphibole-chloritic masses, pseudomorphs (mainly after clinopyroxene), and as a constituent of veins and near-vein halos. The atomic proportions of the amphiboles analyzed were normalized on the basis of 23 oxygen atoms and the cation sum without $\mathrm{Ca}, \mathrm{Na}$, and $\mathrm{K}$ recast to 13. On the Leake's classification diagram (Leake, 1978), our amphibole data plot within the fields of actinolite, actinolitic hornblende, and Mg-hornblende (Fig. 7). We would like to emphasize the similarity of our amphiboles to those from upper levels in Hole 504B (Alt et al., 1985; Ishizuka, 1989). Ishizuka's amphibole compositional range is wider both in $\mathrm{X}(\mathrm{Mg})$ and $\mathrm{Si}$. This seems to correspond to a wider alteration temperature range along the upper part of sheeted dikes than evidenced by the sheeted dikes in our study. Few data from amphiboles in this study plot within the silicic edenite field, but this could result from analytical inaccuracies.

Chlorite (Table 7; Fig. 8) is one of the two main secondary minerals of the diabase dikes. It occurs as a fine background material or in veins, commonly mixed with amphiboles, and as flakes pseudomorphing olivine. On the basis of the analyses of the mineral (Table 7), we ascribed the chlorites to diabanite, pycnochlorite, and, much more rarely, ripidolite. 


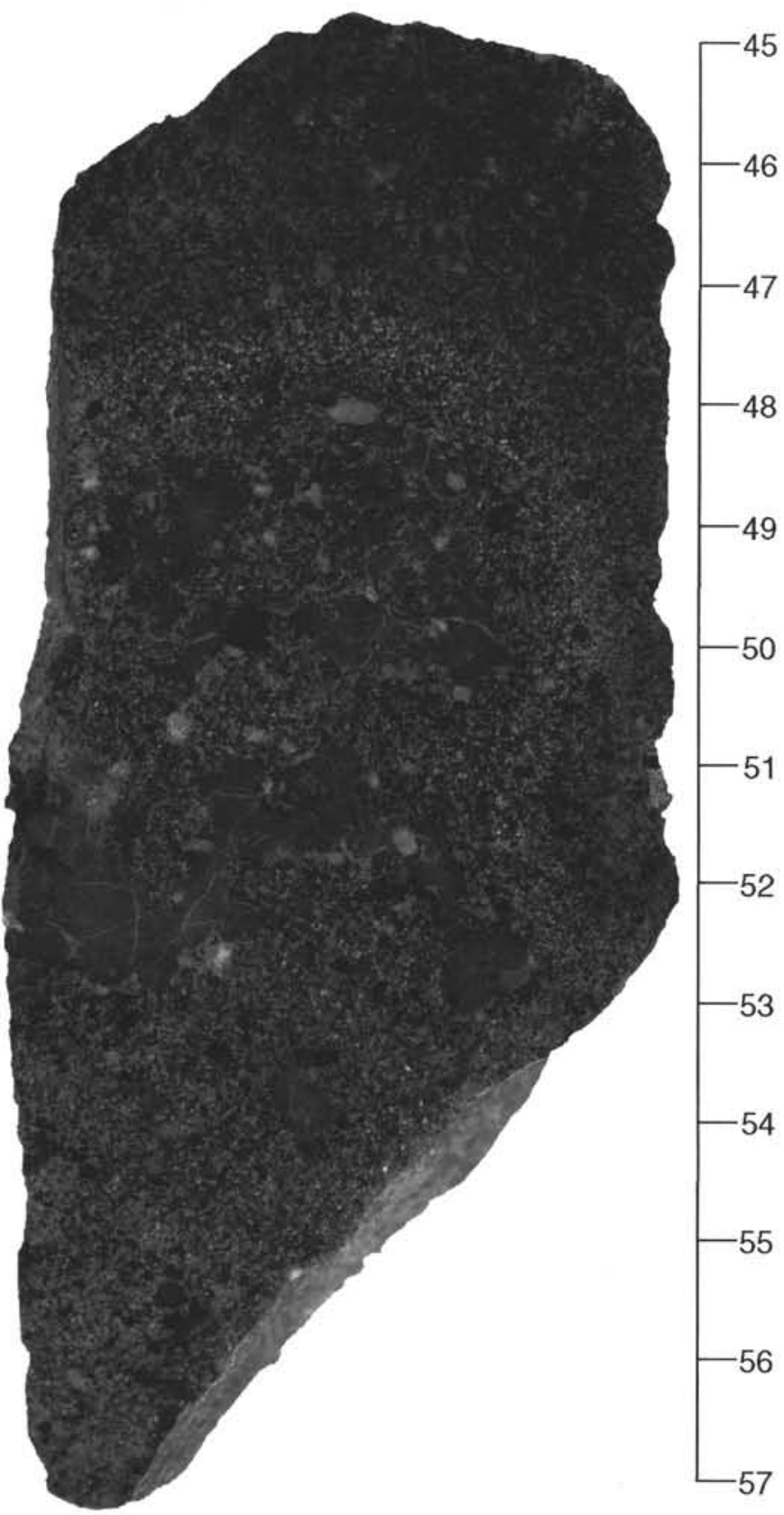

Figure 6. Patches of fine-grained amphibole and chlorite with some altered plagioclase phenocrysts (white) are surrounded by a halo of medium-grained intermediate alteration zone in moderately altered diabase (dark gray), from Sample 140-504B-193R-1, 45-57 cm.

Anhydrite was noticed only as a constituent of epidote-anhydriteprehnite assemblages (EAP in Fig. 1). It usually forms veins in the rock and net-like veinlets replacing plagioclase grains. A microprobe analysis of anhydrite is given in Table 8.

Epidote occurs sporadically as a constituent of epidote-anhydriteprehnite assemblage. Microprobe analyses of epidote are presented in Table 9. Ishizuka (1989) described two epidote types from Hole 504B that differed in $\mathrm{X}\left(\mathrm{Fe}^{3+}\right)$ values: one type associated with laumontite and prehnite (common X[Fe] values about 0.26 ); and a second type in an assemblage with actinolite and prehnite (common $\mathrm{X}[\mathrm{Fe}]=0.19-0.20)$. Our epidotes have $\mathrm{X}(\mathrm{Fe})$ nearly similar to the latter group $(0.21$ and 0.24$)$, which seems to reflect similar conditions.
Table 1. Electron microprobe analyses of olivine phenocrysts.

\begin{tabular}{|c|c|c|c|}
\hline Analysis no.: & 1 & 2 & 3 \\
\hline $\mathrm{SiO}_{2}$ & 39.53 & 40.49 & 40.49 \\
\hline $\mathrm{TiO}_{2}^{2}$ & 0.00 & 0.00 & 0.00 \\
\hline $\mathrm{Al}_{2} \mathrm{O}_{3}$ & 0.00 & 0.06 & 0.06 \\
\hline $\mathrm{FeO}$ & 12.79 & 11.76 & 11.78 \\
\hline $\mathrm{MnO}$ & 0.10 & 0.03 & 0.03 \\
\hline $\mathrm{MgO}$ & 47,65 & 47.68 & 47.68 \\
\hline $\mathrm{CaO}$ & 0.31 & 0.27 & 0.27 \\
\hline Total & 100.38 & 100.29 & $|00.3|$ \\
\hline $\mathrm{Si}$ & 0.98 & 1.00 & 1.00 \\
\hline $\mathrm{Ti}$ & 0.00 & 0.00 & 0.00 \\
\hline $\mathrm{Al}$ & 0.00 & 0.00 & 0.00 \\
\hline $\mathrm{Fe}^{3+}$ & 0.05 & 0.00 & 0.00 \\
\hline $\mathrm{Fe}^{2+}$ & 0.21 & 0.24 & 0.24 \\
\hline $\mathrm{Mn}$ & 0.00 & 0.00 & 0.00 \\
\hline $\mathrm{Mg}$ & 1.75 & 1.75 & 1.75 \\
\hline $\mathrm{Ca}$ & 0.01 & 0.01 & 0.01 \\
\hline $\mathrm{X}(\mathrm{Mg})$ & 0.87 & 0.88 & 0.88 \\
\hline
\end{tabular}

Notes: Major and minor elements measured in weight percent (wt $\%$ ). Analyses 1, $2=$ Sample 140-504B-204R-1, 23-27 cm (Piece 6). Analysis $3=$ Sample 140-504B$200 \mathrm{R}-1,28-30 \mathrm{~cm}$ (Piece 7). $\mathrm{Na}_{2} \mathrm{O}, \mathrm{K}_{2} \mathrm{O}$, and $\mathrm{NiO}$ contents equal 0 in all analyses.

Smectite occurs in insignificant quantities in the recovered core. A microprobe analysis of smectite is listed in Table 10.

Talc (Table 10) participates mainly in partial pseudomorphing after olivine. It forms either fine microvein material or larger flaky plates. Talc compositions fall into two groups. The first has minor Fe, whereas the other contains significant $\mathrm{FeO}$ quantities (5.5-5.9 wt\%) but insignificant amounts of $\mathrm{Al}_{2} \mathrm{O}_{3}$ and $\mathrm{CaO}$. Our ferrous talcs have $\mathrm{X}[\mathrm{Fe}]=0.10-0.11$ (minnesotaite end-member) and bear witness to reductive conditions during their formation.

Some talc grains and aggregates contain fine dusty magnetite or hematite inclusions, which reflect "normal" or oxidative conditions, respectively. We have no good analyses of mix-layered talc-smectites, but would expect them to contain significant $\mathrm{Al}_{2} \mathrm{O}_{3}$.

Titanite occurs as a secondary mineral commonly replacing titanomagnetite or participating in complex pseudomorphs after augite. Its microprobe analysis is given in Table 11.

\section{DISCUSSION}

Compositional and structural features of the Hole 504B core allow us to visualize the complete thermal history of diabase alteration. Taking into account the average seafloor spreading rate $(220 \mathrm{~km}$ per $5.9 \mathrm{Ma}$ or about $3.7 \mathrm{~cm} / \mathrm{yr}$ ), the thickness of the dike sequence drilled during Leg 140 at dip $80^{\circ}$ (about $65 \mathrm{~m}$ ), and assuming that $2 / 3$ of the units are semidikes and the remainder are full dikes (59 units corresponding to approximately 40 dikes), the mean time between dike intrusions can be estimated as $45 \mathrm{yr}$. This corresponds to the time available for intrusion, solidification, and cooling down to a background temperature level of $350^{\circ}-450^{\circ} \mathrm{C}$. The background alteration seems to correspond to several dike intrusion time intervals because groups of neighboring dikes commonly demonstrate similar alteration features. Intrusion of any new dike elevates local temperature and can cause a new alteration episode. The alteration extent depends, among other factors, upon dike thickness and the corresponding amount of heat. Thus, local thermal fluctuations against the regional background of gradual cooling are caused by intrusions of younger dikes. Because predominantly amphibolitic alteration appears to correspond to higher temperatures than chlorite alteration, local relationships between both alteration types offer a clue to the understanding of thermal evolution. However, the poorer core recovery in the intervals rich in chlorite relative to recovery in intervals in which amphibole prevails may have distorted the picture somewhat.

However, in a natural system at any particular moment, the volume of the pore solution is insignificant compared to the volume of 
Table 2. Electron microprobe analyses of magmatic clinopyroxenes.

\begin{tabular}{|c|c|c|c|c|c|c|}
\hline Analysis no.: & 1 & 2 & 3 & 4 & 5 & 6 \\
\hline $\mathrm{SiO}_{2}$ & 54.80 & 51.66 & 53.99 & 52.51 & 53.28 & 0.91 \\
\hline $\mathrm{TiO}_{2}^{-}$ & 0.40 & 0.40 & 0.00 & 0.10 & 0.47 & 0.52 \\
\hline $\mathrm{Al}_{2} \mathrm{O}_{3}$ & 3.04 & 4.38 & 1.51 & 4.90 & 5.16 & 3.53 \\
\hline $\mathrm{FeO}$ & 4.98 & 6.69 & 7.67 & 14.97 & 13.93 & 6.33 \\
\hline $\mathrm{MnO}$ & 0.45 & 0.13 & 0.15 & 0.26 & 0.21 & 0.01 \\
\hline $\mathrm{MgO}$ & 18.20 & 15.82 & 17.48 & 13.66 & 14.39 & 16.31 \\
\hline $\mathrm{CaO}$ & 18.49 & 19.80 & 18.48 & 10.91 & 11.12 & 20.23 \\
\hline $\mathrm{Na}_{2} \mathrm{O}$ & 0.00 & 0.19 & 0.20 & 1.19 & 1.74 & 0.27 \\
\hline $\mathrm{K}_{2} \mathrm{O}$ & 0.00 & 0.00 & 0.00 & 0.00 & 0.01 & 0.00 \\
\hline $\mathrm{Cr}_{2} \mathrm{O}_{3}$ & 0.47 & 0.00 & 0.00 & 0.00 & 0.00 & 0.13 \\
\hline Total & 100.83 & 99.07 & 99.48 & 98.50 & 100.31 & 98.24 \\
\hline $\mathrm{Si}$ & 1.98 & 1.91 & 1.99 & 1.99 & 1.97 & 1.90 \\
\hline $\mathrm{Ti}$ & 0.01 & 0.01 & 0.00 & 0.00 & 0.01 & 0.01 \\
\hline Al & 0.13 & 0.19 & 0.07 & 0.22 & 0.22 & 0.16 \\
\hline $\mathrm{Fe}_{\mathrm{tot}}$ & 0.15 & 0.21 & 0.24 & 0.47 & 0.43 & 0.20 \\
\hline $\mathrm{Mn}$ & 0.01 & 0.00 & 0.00 & 0.01 & 0.01 & 0.00 \\
\hline $\mathrm{Mg}$ & 0.98 & 0.87 & 0.96 & 0.77 & 0.79 & 0.91 \\
\hline $\mathrm{Ca}$ & 0.72 & 0.79 & 0.73 & 0.44 & 0.44 & 0.81 \\
\hline $\mathrm{Na}$ & 0.00 & 0.01 & 0.01 & 0.09 & 0.12 & 0.02 \\
\hline K & 0.00 & 0.00 & 0.00 & 0.00 & 0.00 & 0.00 \\
\hline $\mathrm{Cr}$ & 0.01 & 0.00 & 0.00 & 0.00 & 0.00 & 0.00 \\
\hline $\mathrm{X}(\mathrm{Mg})$ & 0.86 & 0.81 & 0.80 & 0.62 & 0.64 & 0.82 \\
\hline Analysis no.: & 7 & 8 & 9 & 10 & 11 & 12 \\
\hline $\mathrm{SiO}_{2}$ & 51.31 & 53.77 & 52.43 & 53.00 & 49.73 & 42.20 \\
\hline $\mathrm{TiO}_{2}$ & 0.50 & 0.13 & 0.42 & 0.35 & 0.48 & 3.90 \\
\hline $\mathrm{Al}_{2} \mathrm{O}_{3}$ & 4.61 & 3.08 & 3.38 & 3.48 & 3.04 & 13.68 \\
\hline $\mathrm{FeO}$ & 6.11 & 6.51 & 6.50 & 5.52 & 5.92 & 14.25 \\
\hline $\mathrm{MnO}$ & 0.05 & 0.22 & 0.10 & 0.05 & 0.31 & 0.10 \\
\hline $\mathrm{MgO}$ & 16.10 & 17.04 & 17.62 & 16.83 & 20.19 & 11.44 \\
\hline $\mathrm{CaO}$ & 20.44 & 20.66 & 18.34 & 19.94 & 18.69 & 11.32 \\
\hline $\mathrm{Na}_{2} \mathrm{O}$ & 0.26 & 0.00 & 0.24 & 0.30 & 0.54 & 2.74 \\
\hline $\mathrm{K}_{2} \mathrm{O}$ & 0.00 & 0.00 & 0.00 & 0.00 & 0.05 & 0.00 \\
\hline $\mathrm{Cr}_{2} \mathrm{O}_{3}$ & 0.38 & 0.13 & 0.23 & 0.37 & 0.67 & \\
\hline Total & 99.76 & 101.54 & 99.26 & 99.84 & 99.62 & 99.63 \\
\hline $\mathrm{Si}$ & 1.88 & 1.94 & 1.93 & 1.94 & $\mathrm{I} .80$ & 1.57 \\
\hline $\mathrm{Ti}$ & 0.01 & 0.00 & 0.01 & 0.01 & 0.01 & 0.11 \\
\hline $\mathrm{Al}$ & 0.20 & 0.13 & 0.15 & 0.15 & 0.13 & 0.60 \\
\hline $\mathrm{Fe}_{t o t}$ & 0.19 & 0.20 & 0.20 & 0.17 & 0.18 & 0.44 \\
\hline $\mathrm{Mn}$ & 0.00 & 0.01 & 0.00 & 0.00 & 0.01 & 0.00 \\
\hline $\mathrm{Mg}$ & 0.88 & 0.92 & 0.97 & 0.92 & 1.09 & 0.63 \\
\hline $\mathrm{Ca}$ & 0.80 & 0.80 & 0.72 & 0.78 & 0.72 & 0.45 \\
\hline $\mathrm{Na}$ & 0.02 & 0.00 & 0.02 & 0.02 & 0.04 & 0.20 \\
\hline K & 0.00 & 0.00 & 0.00 & 0.00 & 0.00 & 0.00 \\
\hline $\mathrm{Cr}$ & 0.01 & 0.00 & 0.01 & 0.01 & 0.02 & 0.00 \\
\hline $\mathrm{X}(\mathrm{Mg})$ & 0.82 & 0.82 & 0.83 & 0.84 & 0.85 & 0.59 \\
\hline Analysis no.: & 13 & 14 & 15 & 16 & 17 & 18 \\
\hline $\mathrm{SiO}_{2}$ & 53.73 & 52.77 & 53.88 & 52.04 & 51.74 & 53.84 \\
\hline $\mathrm{TiO}_{2}^{2}$ & 0.15 & 0.25 & 0.40 & 0.47 & 0.48 & 0.28 \\
\hline $\mathrm{Al}_{2} \mathrm{O}_{3}$ & 2.66 & 2.49 & 1.93 & 3.50 & 3.72 & 2.21 \\
\hline $\mathrm{FeO}^{3}$ & 11.22 & 12.64 & 17.54 & 5.63 & 5.80 & 6.91 \\
\hline $\mathrm{MnO}$ & 0.15 & 0.21 & 0.28 & 0.10 & 0.79 & 0.17 \\
\hline $\mathrm{MgO}$ & 14.28 & 14.59 & 14.28 & 15.75 & 16.38 & 17.79 \\
\hline $\mathrm{CaO}$ & 16.87 & 16.24 & 11.25 & 21.32 & 21.05 & 17.74 \\
\hline $\mathrm{Na}_{2} \mathrm{O}$ & 0.50 & 0.57 & 0.73 & 0.00 & 0.05 & 0.18 \\
\hline $\mathrm{K}_{2} \mathrm{O}$ & 0.00 & 0.00 & 0.00 & 0.00 & 0.00 & 0.04 \\
\hline $\mathrm{Cr}_{2} \mathrm{O}_{3}$ & 0.15 & 0.00 & 0.00 & 0.57 & 0.79 & 0.00 \\
\hline Total & 99.71 & 99.76 & 100.29 & 99.38 & 100.80 & 99.16 \\
\hline $\mathrm{Si}$ & 2.01 & 1.98 & 2.03 & 1.93 & 1.89 & 1.99 \\
\hline $\mathrm{Ti}$ & 0.00 & 0.01 & 0.01 & 0.01 & 0.01 & 0.01 \\
\hline Al & 0.12 & 0.11 & 0.09 & 0.15 & 0.16 & 0.10 \\
\hline $\mathrm{Fe}_{\mathrm{tO}}$ & 0.35 & 0.40 & 0.55 & 0.17 & 0.18 & 0.21 \\
\hline $\mathrm{Mn}$ & 0.00 & 0.01 & 0.01 & 0.00 & 0.02 & 0.01 \\
\hline $\mathrm{Mg}$ & 0.80 & 0.81 & 0.80 & 0.87 & 0.89 & 0.98 \\
\hline $\mathrm{Ca}$ & 0.68 & 0.65 & 0.45 & 0.85 & 0.82 & 0.70 \\
\hline $\mathrm{Na}$ & 0.04 & 0.04 & 0.05 & 0.00 & 0.00 & 0.01 \\
\hline K & 0.00 & 0.00 & 0.00 & 0.00 & 0.00 & 0.00 \\
\hline $\mathrm{Cr}$ & 0.00 & 0.00 & 0.00 & 0.02 & 0.02 & 0.00 \\
\hline $\mathrm{X}(\mathrm{Mg})$ & 0.69 & 0.67 & 0.59 & 0.83 & 0.82 & 0.82 \\
\hline
\end{tabular}

Notes: Major and minor elements measured in weight percent $(w t \%)$. Analysis $1=\mathrm{Sam}$ ple 140-504B-198R-1, 66-68 cm (Piece 17). Analyses 2-8 = Sample 137-504B173R-2, 14-16 cm (Piece 2). Analyses 9, $10=$ Sample 140-504B-226R-2, 17-19 $\mathrm{cm}$ (Piece 2). Analysis 11, 12 = Sample 140-504B-208R-1, 30-33 cm (Piece 19A). Analyses $13-15=$ Sample 137-504B-177R-1, 1-3 cm (Piece 1). Analyses 16-18= Sample 140-504B-214R-1, 18-20 cm (Piece 4). Analyses 1, 6-8, 9, 10, 13, 16, and 17 from phenocrysts; Analyses $2-5,11,12,14,15$, and 18 from the groundmass.
Table 3. Microprobe analyses of plagioclases.

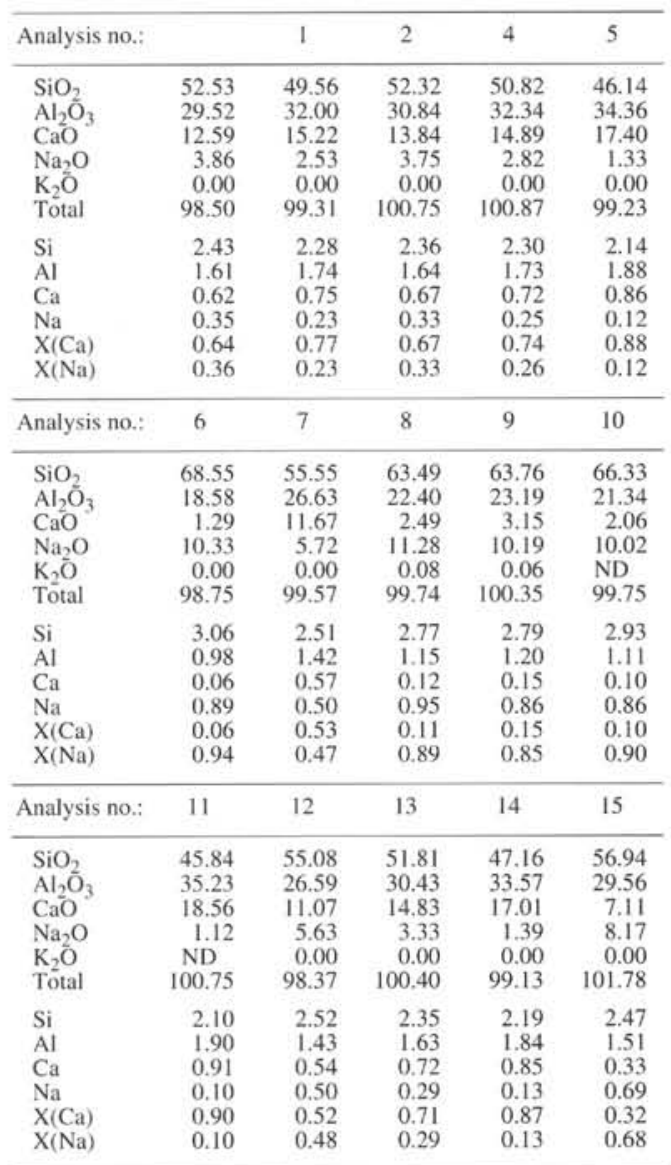

Note: Major and minor elements measured in weight percent (wt\%). Analyses I, 2 = Sample 140-504B-198R-1, 66-68 cm (Piece 17). Analyses 3, $4=$ Sample 140 504B-173R-2, 14-16 cm (Piece 2). Analysis 5 = Sample 140-504B-217R-1, 17-19 $\mathrm{cm}$ (Piece 4). Analysis $6=$ Sample 137-504B-177R-1, 1-3 cm (Piece 1). Analyses 7-9 = Sample 140-504B-217R-1, 0-2 cm (Piece 1). Analyses 10-12 = Sample 140504B-222R-1, 19-21 cm (Piece IF). Analyses 13-15 = Sample 140-504B-186R-1. 103-105 cm (Piece 14B). Analyses 1-5, 11, 13, and 14 from phenocrysts; Analyses 6 and 15 from altered phenocrysts; Analyses 7 and 12 from strongly altered phenocrysts; and Analyses 8-10 from veins. $\mathrm{ND}=$ not determined.

the rock, although the total volume of the solution infiltrating through the rock may be fairly large. Assuming constant temperature and composition of the solution (both being the main factors of the secondary alteration of diabases), the total amount of solution passing through the rock accounts for the intensity of alteration. Alternating crosscutting relations of chloritic and amphibolitic veins provide evidence for numerous temperature and/or solution composition fluctuations over the column investigated.

Two morphologically different vein types (with and without nearvein halos) we think correspond to different fluid pressures in pores and fractures. Veins without halos originated under nearly equal pore and fracture fluid pressures by precipitation of a secondary mineral in the free space of a fracture. We think that fluid pressure inside veins of the other type markedly exceeded that in wall rock pores. The mineralogical features discussed above support the infiltration character of their metasomatic zonation. The deficient pore fluid pressure could be attributed either to a specific position in a hydrothermal cell (e.g., as in the basalt part of Hole 504B, where an underpressure amounting to about $10 \mathrm{~atm}$ with respect to hydrostatic pressure was determined; Zoback and Anderson, 1983), or to an excess of fluid pressure in the fracture system as a result of heating the circulating fluids. Infiltrate-metasomatic veins are typical of the upper part of the 
Table 4. Electron microprobe analyses of magnetite, spinels, and chromite.

\begin{tabular}{lrrrr}
\hline Analysis no.: & \multicolumn{1}{c}{1} & \multicolumn{1}{c}{2} & \multicolumn{1}{c}{3} & \multicolumn{1}{c}{4} \\
\hline $\mathrm{TiO}_{2}$ & 32.08 & 0.42 & 0.23 & 0.23 \\
$\mathrm{Cr}_{2} \mathrm{O}_{3}$ & 0.07 & 33.44 & 28.55 & 28.55 \\
$\mathrm{Al}_{2} \mathrm{O}_{3}$ & $\mathrm{ND}$ & 28.46 & 38.01 & 0.07 \\
$\mathrm{FeO}$ & 66.94 & 25.78 & 17.50 & 38.01 \\
$\mathrm{MnO}$ & 0.41 & 0.30 & 0.05 & 17.50 \\
$\mathrm{MgO}$ & 1.06 & 10.84 & 16.23 & 0.05 \\
$\mathrm{NiO}$ & 0.00 & $\mathrm{ND}$ & 0.01 & 16.23 \\
$\mathrm{ZnO}$ & 0.00 & 0.00 & $\mathrm{ND}$ & \multicolumn{1}{c}{$\mathrm{ND}$} \\
$\mathrm{Total}$ & 100.56 & 99.24 & 100.57 & 100.57 \\
$\mathrm{Ti}$ & 0.88 & 0.01 & 0.01 & 0.00 \\
$\mathrm{Cr}$ & 0.00 & 0.81 & 0.73 & 0.64 \\
$\mathrm{Al}$ & & 1.02 & 1.26 & 0.01 \\
$\mathrm{Fe}$ & 0.23 & 0.15 & 0.09 & 1.26 \\
$\mathrm{Fe}$ & 1.81 & 0.51 & 0.32 & 0.09 \\
$\mathrm{Mn}$ & 0.01 & 0.01 & 0.00 & 0.32 \\
$\mathrm{Mg}$ & 0.06 & 0.49 & 0.68 & 0.00 \\
$\mathrm{Ni}$ & 0.00 & 0.00 & 0.00 & 0.68 \\
$\mathrm{Zn}$ & 0.00 & 0.00 & 0.00 & 0.00 \\
& & & & \\
& & & &
\end{tabular}

Notes: Major and minor elements measured in weight percent (wt\%). Analysis I = Sample 140-504B-198R-1, 66-68 cm (Piece 17). Analyses 2, 3 = Sample 140-504B 226R-2, 17-19 cm (Piece 2). Analysis 4= Sample 140-504B-204R-1, 14-16 cm (Piece 4). Analysis 1 is a skeletal crystal of magmatic magnetite; Analyses 2-4 are magmatic $\mathrm{Cr}$-spinels. $\mathrm{ND}=$ not determined.

Table 5. Electron microprobe analyses of secondary ilmenite.

\begin{tabular}{|c|c|c|c|c|c|}
\hline Analysis no.: & 1 & 2 & 3 & 4 & 5 \\
\hline $\mathrm{TiO}_{2}$ & 48.37 & 49.99 & 44.54 & 46.00 & 47.05 \\
\hline $\mathrm{FeO}^{-}$ & 47.73 & 47.77 & 52.45 & 50.00 & 45.56 \\
\hline $\mathrm{MnO}$ & 1.65 & 1.65 & 0.90 & 1.14 & 3.28 \\
\hline $\mathrm{MgO}$ & 0.41 & 0.00 & 0.00 & 0.00 & 0.48 \\
\hline Total & 98.16 & 99.41 & 97.89 & 97.14 & 96.37 \\
\hline $\mathrm{Ti}_{2}$ & 0.93 & 0.95 & 0.86 & 0.89 & 0.92 \\
\hline $\mathrm{Fe}_{2+}^{3+}$ & 0.14 & 0.09 & 0.28 & 0.21 & 0.16 \\
\hline $\mathrm{Fe}^{2+}$ & 0.88 & 0.92 & 0.84 & 0.87 & 0.83 \\
\hline $\mathrm{Mn}$ & 0.04 & 0.04 & 0.02 & 0.02 & 0.07 \\
\hline $\mathrm{Mg}$ & 0.02 & 0.00 & 0.00 & 0.00 & 0.02 \\
\hline Analysis no.: & 6 & 7 & 8 & 9 & 10 \\
\hline $\mathrm{TiO}_{2}$ & 46.69 & 47.10 & 46.55 & 47.9 & 48.94 \\
\hline $\mathrm{FeO}$ & 48.76 & 48.02 & 48.15 & 48,74 & 48.66 \\
\hline $\mathrm{MnO}$ & 1.91 & 1.78 & 1.78 & 2.13 & 2.05 \\
\hline $\mathrm{MgO}$ & 0.15 & 0.15 & 0.00 & 0.00 & 0.00 \\
\hline Total & 97.51 & 97.05 & 96.48 & 98.81 & 99.65 \\
\hline $\mathrm{Ti}_{3}$ & 0.90 & 0.92 & 0.91 & 0.92 & 0.93 \\
\hline $\mathrm{Fe}^{3+}$ & 0.19 & 0.17 & 0.18 & 0.16 & 0.14 \\
\hline $\mathrm{Fe}^{2+}$ & 0.86 & 0.87 & 0.87 & 0.87 & 0.89 \\
\hline Mn & 0.04 & 0.04 & 0.04 & 0.05 & 0.04 \\
\hline $\mathrm{Mg}$ & 0.01 & 0.01 & 0.00 & 0.00 & 0.00 \\
\hline Analysis no: & 11 & 12 & 13 & 14 & \\
\hline $\mathrm{TiO}_{2}$ & 46.55 & 47.94 & 48.96 & 48.72 & \\
\hline $\mathrm{FeO}$ & 47.88 & 48.46 & 47.88 & 46.89 & \\
\hline $\mathrm{MnO}$ & 1.79 & 2.14 & 0.68 & 2.17 & \\
\hline $\mathrm{MgO}$ & 0.00 & 0.00 & 0.12 & 0.18 & \\
\hline Total & 96.22 & 98.54 & 97.64 & 97.96 & \\
\hline $\mathrm{Ti}_{3}$ & 0.92 & 0.92 & 0.95 & 0.94 & \\
\hline $\mathrm{Fe}^{3+}$ & 0.17 & 0.16 & 0.10 & 0.12 & \\
\hline $\mathrm{Fe}^{2+}$ & 0.88 & 0.87 & 0.93 & 0.89 & \\
\hline $\mathrm{Mn}$ & 0.04 & 0.05 & 0.01 & 0.05 & \\
\hline $\mathrm{Mg}$ & 0.00 & 0.00 & 0.00 & 0.01 & \\
\hline
\end{tabular}

Note: Major and minor elements measured in weight percent (wt\%). Analyses 1, 2 = Sample 140-504B-219R-1, 13-15 cm (Piece 4). Analyses 3, 4 = Sample 140-504B232R-1. 12-14 cm (Piece IF). Analysis $5=$ Sample 140-504B-227R-2, $1 \mathrm{~cm}$ (Piece 16). Analyses $6,7=$ Sample 140-504B-208R-1, 30-33 cm (Piece 7). Analysis 8-12 $=$ Sample 140-504B-204R-1, 44-46 cm (Piece 11). Analysis $13=$ Sample 140504B-203R-1, 57-59 cm (Piece 15). Analysis $14=$ Sample 140-504B-211R-1, 54 $56 \mathrm{~cm}$ (Piece 12).

seafloor basement drilled in Hole 504B during Leg 69 and are related to oxidative alteration caused by the breakthrough of fresh seawater (Pertsev and Boronokhin, 1983a, 1983b). Infiltrate-metasomatic veins occurring in the sheeted dike complex correspond mineralogically to the background alteration. These veins both cut those of filling or are cut by them, which shows evidence for broadly differing
Table 6. Electron microprobe analyses of amphiboles.

\begin{tabular}{|c|c|c|c|c|c|c|}
\hline Analysis no.: & 1 & 2 & 3 & 4 & 5 & \\
\hline $\mathrm{SiO}_{2}$ & 50.31 & 50.72 & 50.93 & 51.16 & 52.88 & \\
\hline $\mathrm{Al}_{2} \mathrm{O}_{3}$ & 4.65 & 4.25 & 4.29 & 4.67 & 4.18 & \\
\hline $\mathrm{FeO}$ & 15.08 & 19.21 & 18.83 & 16.00 & 16.28 & \\
\hline $\mathrm{MnO}$ & 0.04 & 0.23 & 0.34 & 0.25 & 0.28 & \\
\hline $\mathrm{MgO}$ & 15.90 & 12.37 & 11.52 & 13.68 & 13.58 & \\
\hline $\mathrm{CaO}$ & 10.14 & 10.80 & 11.04 & 10.10 & 10.91 & \\
\hline $\mathrm{Na}_{2} \mathrm{O}$ & 2.37 & 0.47 & 0.39 & 0.57 & 0.30 & \\
\hline $\mathrm{K}_{2} \mathrm{O}$ & 0.05 & 0.06 & 0.01 & 0.08 & 0.04 & \\
\hline Total & 98.79 & 98.11 & 97.37 & 96.56 & 98.60 & \\
\hline $\mathrm{Si}$ & 7.09 & 7.29 & 7.43 & 7.34 & 7.47 & \\
\hline $\mathrm{Ti}$ & 0.03 & 0.00 & 0.00 & 0.01 & 0.02 & \\
\hline Al & 0.77 & 0.72 & 0.74 & 0.79 & 0.70 & \\
\hline $\mathrm{Fe}$ & 1.77 & 2.31 & 2.29 & 1.92 & 1.92 & \\
\hline $\mathrm{Mn}$ & 0.00 & 0.03 & 0.04 & 0.03 & 0.03 & \\
\hline $\mathrm{Mg}$ & 3.34 & 2.65 & 2.50 & 2.92 & 2.86 & \\
\hline $\mathrm{Ca}$ & 1.53 & 1.66 & 1.72 & 1.55 & 1.65 & \\
\hline $\mathrm{Na}$ & 0.65 & 0.13 & 0.11 & 0.16 & 0.08 & \\
\hline & 0.01 & 0.01 & 0.00 & 0.01 & 0.01 & \\
\hline $\mathrm{X}(\mathrm{Mg})$ & 0.65 & 0.53 & 0.52 & 0.60 & 0.59 & \\
\hline Analysis no.: & 6 & 7 & 8 & 9 & 10 & \\
\hline $\mathrm{SiO}_{2}$ & 51.66 & 52.73 & 54.18 & 50.31 & 54.33 & \\
\hline $\mathrm{TiO}_{2}$ & 0.13 & 0.10 & 0.43 & 0.25 & 0.28 & \\
\hline $\mathrm{Al}_{2} \mathrm{O}_{3}$ & 5.44 & 4.76 & 4.59 & 4.65 & 2.23 & \\
\hline $\mathrm{FeO}$ & 15.01 & 14.23 & 12.11 & 15.09 & 17.21 & \\
\hline $\mathrm{MnO}$ & 0.00 & 0.09 & 0.00 & 0.04 & 0.21 & \\
\hline $\mathrm{MgO}$ & 13.60 & 13.78 & 15.97 & 15.90 & 13.23 & \\
\hline $\mathrm{CaO}$ & 10.38 & 11.19 & 10.70 & 10.14 & 9.96 & \\
\hline $\mathrm{Na}_{2} \mathrm{O}$ & 0.61 & 0.51 & 0.67 & 2.37 & 0.70 & \\
\hline $\mathrm{K}_{2} \mathrm{O}$ & 0.02 & 0.02 & 0.04 & 0.05 & 0.00 & \\
\hline Total & 96.85 & 97.41 & 98.69 & 98.80 & 98.15 & \\
\hline $\mathrm{Si}$ & 7.38 & 7.54 & 7.51 & 7.09 & 7.73 & \\
\hline $\mathrm{Ti}$ & 0.01 & 0.01 & 0.04 & 0.03 & 0.03 & \\
\hline Al & 0.92 & 0.80 & 0.750 & 0.77 & 0.37 & \\
\hline $\mathrm{Fe}$ & 1.79 & 1.70 & 1.40 & 1.77 & 2.04 & \\
\hline $\mathrm{Mn}$ & 0.00 & 0.01 & 0.00 & 0.00 & 0.03 & \\
\hline $\mathrm{Mg}$ & 2.90 & 2.94 & 3.30 & 3.34 & 2.80 & \\
\hline $\mathrm{Ca}$ & 1.59 & 1.71 & 1.59 & 1.53 & 1.52 & \\
\hline $\mathrm{Na}$ & 0.17 & 0.14 & 0.18 & 0.65 & 0.19 & \\
\hline K & 0.00 & 0.00 & 0.01 & 0.01 & 0.00 & \\
\hline $\mathrm{X}(\mathrm{Mg})$ & 0.62 & 0.63 & 0.70 & 0.65 & 0.58 & \\
\hline Analysis no.: & 11 & 12 & 13 & 14 & 15 & 16 \\
\hline $\mathrm{SiO}_{2}$ & 54.72 & 53.99 & 50.16 & 51.85 & 52.08 & 53.30 \\
\hline $\mathrm{TiO}_{2}$ & 0.22 & 0.28 & 0.15 & 0.08 & 0.23 & 0.03 \\
\hline $\mathrm{Al}_{2} \mathrm{O}_{3}$ & 1.91 & 3.33 & 13.80 & 2.55 & 6.48 & 2.27 \\
\hline $\mathrm{FeO}$ & 14.99 & 16.22 & 13.17 & 14.36 & 14.76 & 14.58 \\
\hline $\mathrm{MnO}$ & 0.18 & 0.21 & 0.14 & 0.19 & 0.18 & 0.17 \\
\hline $\mathrm{MgO}$ & 15.17 & 13.83 & 10.48 & 14.28 & 12.37 & 14.52 \\
\hline $\mathrm{CaO}$ & 10.51 & 10.06 & 10.13 & 12.70 & 12.88 & 12.51 \\
\hline $\mathrm{Na}_{2} \mathrm{O}$ & 0.59 & 0.43 & 1.75 & 0.40 & 0.85 & 0.84 \\
\hline $\mathrm{K}_{2} \mathrm{O}$ & 0.00 & 0.00 & 0.06 & 0.01 & 0.01 & 0.02 \\
\hline Total & 98.29 & 98.35 & 99.84 & 96.42 & 99.84 & 98.24 \\
\hline $\mathrm{Si}$ & 7.70 & 7.59 & 6.99 & 7.63 & 7.46 & 7.70 \\
\hline $\mathrm{Ti}$ & 0.02 & 0.03 & 0.02 & 0.01 & 0.02 & 0.00 \\
\hline Al & 0.32 & 0.55 & 2.27 & 0.44 & 1.09 & 0.39 \\
\hline $\mathrm{Fe}$ & 1.76 & 1.90 & 1.53 & 1.76 & 1.76 & 1.76 \\
\hline $\mathrm{Mn}$ & 0.02 & 0.03 & 0.02 & 0.02 & 0.02 & 0.02 \\
\hline $\mathrm{Mg}$ & 3.18 & 2.90 & 2.18 & 3.13 & 2.64 & 3.13 \\
\hline $\mathrm{Ca}$ & 1.58 & 1.52 & 1.51 & 2.00 & 1.98 & 1.94 \\
\hline $\mathrm{Na}$ & 0.16 & 0.12 & 0.47 & 0.11 & 0.24 & 0.24 \\
\hline $\mathrm{K}$ & 0.00 & 0.00 & 0.01 & 0.00 & 0.00 & 0.00 \\
\hline$\hat{\mathrm{X}}(\mathrm{Mg})$ & 0.64 & 0.60 & 0.58 & 0.64 & 0.60 & 0.64 \\
\hline
\end{tabular}

Note: Major and minor elements measured in weight percent $(w t \%)$. Analyses $1=$ Sample 140-504B-2IIR-1, 54-56 cm (Piece 12). Analysis $2=$ Sample 140-504B-207R1. 85-87 cm. Analyses $3=$ Sample 140-504B-208R-1, 85-87 cm (Piece 19). Analyses 4, 5 = Sample 140-504B-208R-1, 30-33 cm (Piece 7). Analysis $6=$ Sample 140504B-203R-1, 33-35 cm (Piece 10). Analyses 7, 8 = Sample 137-504B-173R-1, 14-16 cm (Piece 2). Analysis $9=$ Sample 140-504B-214R-1, 18-20 cm (Piece 4). Analyses $10-12=$ Sample 140-504B-226R-2, 17-19 cm (Piece 2). Analysis $13=$ Sample 140-504B-214R-1, 18-20 cm (Piece 4). Analyses 14-16= Sample 140504B-219R-1, 7-11 cm (Piece 3). All amphiboles from the groundmass.

ratios of pore and fracture pressures. These differences could be caused by temperature fluctuations resulting from intrusions of younger dikes, which could produce new, smaller hydrothermal cells with deficient pore pressure.

We could not find any visible differences between smaller patches of complete alteration or "amygdules" and the larger ones or "halos" as described by the shipboard scientific party (Dick, Erzinger, Stok- 


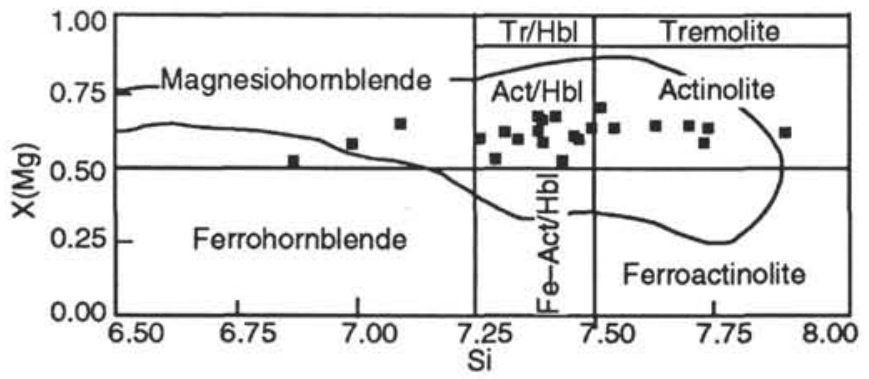

Figure 7. Composition of amphiboles from Hole 504B samples plotted on Leake's diagram (Leake, 1978). The curve in the diagram outlines the compositional field of the amphiboles from Ishizuka (1989).

king, et al., 1992) either in morphology or in compositional features. We suppose it is difficult to explain their appearance by filling with felt-like amphibole without any geometrical selection and rhythmic morphology. Zones regularly surrounding the patches in a manner similar to those near veins have features of infiltrate metasomatic genesis. Dissolution of the rock accompanied by precipitation of new minerals seems to be the main cause of the patches' appearance. Such local zones of high permeability could be caused by dilatation and thermal contraction in cooling dikes.

Allochemical chlorite-amphibole alteration in the sheeted dike complex contain either ilmenite or titanite. Ilmenite-bearing rocks obviously originated at lower $\mathrm{CaO}$ activity than those containing titanite. We assume that these differences are caused by changes in temperature. As temperature elevation stabilizes amphibole at the expense of chlorite, it leads to progressive dissolution of the latter and to a corresponding decrease of $\mathrm{CaO}$ activity. Hence, the ilmenite assemblages appear to have formed under slightly higher temperatures.

Epidote-prehnite-anhydrite alteration contrasts with chlorite-amphibole alteration in its oxidative character. The presence of these minerals is probably caused by fresh oxidative seawater penetrating along younger dike contacts. However, this assumption does not provide a specific mechanism to maintain oxidative fluid chemistry during its penetration through 1.5 to $2 \mathrm{~km}$ of rock. Thus, many questions concerning these types of alteration remain to be answered. As a result of the stability of several calcic minerals in oxidative media at the temperatures between $350^{\circ}$ and $450^{\circ} \mathrm{C}, \mathrm{CaO}$ appears to be thermodynamically inert, and the leaching of $\mathrm{MgO}$ from the rocks is greater than that of $\mathrm{CaO}$. However, when changing to a more reduced medium, the tendency is less marked, if not reversed. The persistent spatial link between the epidote-prehnite-anhydrite alteration with the areas of oxidation and enrichment in $\mathrm{CaO}$ near younger dikes implies that these minerals can be considered separately and related to different processes and portions of solutions (Dick. Erzinger, Stokking, et al., 1992).

Lack of valid pressure-temperature reconstructions of polymineral assemblages causes estimates of these to be rather arbitrary. Because mineral equilibria that are satisfactory pressure indicators in the metabasaltic system work well at pressures exceeding 4-7 kbar (at low temperatures), we had to estimate pressure by means of direct calculations as overburden pressure. At the maximum depth of $2 \mathrm{~km}$ at the bottom of the hole, the pressure during alteration is constrained to lie between the hydrostatic conditions appropriate for a crack network open to the seafloor and the lithostatic conditions appropriate for an impermeable rock matrix. It is worth noting that, in this context, the pressures found for many fluid inclusions in altered rocks drilled beneath the seafloor lie between the hydrostatic minimum and the lithostatic maximum (e.g., Kelley and Gillis, 1993). Thus, the minimum pressure of alteration at the bottom of Hole 504B would be about 550 bars, whereas the maximum (including the $3.5 \mathrm{~km}$ of water over the seafloor) would be about 1000 bars. The temperatures of mineral equilibria for similar parageneses were estimated by the experimental and calculated diagram of Liou et al. (1985).
Table 7. Electron microprobe analyses of groundmass chlorite.

\begin{tabular}{|c|c|c|c|c|c|}
\hline Analysis no.: & 1 & 2 & 3 & 4 & 5 \\
\hline $\mathrm{SiO}_{2}$ & 30.16 & 29.39 & 31.02 & 30.91 & 29.90 \\
\hline $\mathrm{TiO}_{2}^{2}$ & 0.00 & 0.00 & 0.00 & 0.00 & 0.00 \\
\hline $\mathrm{Al}_{2} \mathrm{O}_{3}$ & 18.75 & 18.14 & 15.38 & 18.05 & 18.48 \\
\hline $\mathrm{FeO}$ & 22.79 & 22.78 & 23.59 & 20.94 & 20.32 \\
\hline $\mathrm{MnO}$ & 0.25 & 0.13 & 0.13 & 0.03 & 0.08 \\
\hline $\mathrm{MgO}$ & 17.99 & 17.53 & 17.71 & 18.59 & 17.88 \\
\hline $\mathrm{CaO}$ & 0.69 & 0.67 & 0.88 & 0.11 & 0.08 \\
\hline $\mathrm{Na}_{2} \mathrm{O}$ & 0.00 & 0.00 & 0.12 & 0.34 & 0.36 \\
\hline $\mathrm{K}_{2} \mathrm{O}$ & 0.00 & 0.00 & 0.00 & 0.00 & 0.06 \\
\hline Total & 90.63 & 88.64 & 88.83 & 88.97 & 87.16 \\
\hline $\mathrm{Si}$ & 6.09 & 6.08 & 6.43 & 6.30 & 6.22 \\
\hline $\mathrm{Ti}$ & 0.00 & 0.00 & 0.00 & 0.00 & 0.00 \\
\hline Al & 4.46 & 4.42 & 3.76 & 4.33 & 4.53 \\
\hline $\mathrm{Fe}$ & 3.84 & 3.93 & 4.08 & 3.56 & 3.53 \\
\hline $\mathrm{Mn}$ & 0.04 & 0.02 & 0.02 & 0.01 & 0.01 \\
\hline $\mathrm{Mg}$ & 5.41 & 5.40 & 5.47 & 5.64 & 5.54 \\
\hline $\mathrm{Ca}$ & 0.15 & 0.15 & 0.20 & 0.02 & 0.02 \\
\hline $\mathrm{Na}$ & 0.00 & 0.00 & 0.05 & 0.13 & 0.15 \\
\hline K & 0.00 & 0.00 & 0.00 & 0.00 & 0.02 \\
\hline $\mathrm{X}(\mathrm{Mg})$ & 0.54 & 0.54 & 0.54 & 0.56 & 0.56 \\
\hline Analysis no.: & 6 & 7 & 8 & 9 & 10 \\
\hline $\mathrm{SiO}_{2}$ & 28.45 & 26.10 & 30.80 & 29.77 & 29.30 \\
\hline $\mathrm{TiO}_{2}^{2}$ & 0.00 & 0.12 & 0.00 & 0.00 & 0.03 \\
\hline $\mathrm{Al}^{2} \mathrm{O}_{3}$ & 17.94 & 19.81 & 18.13 & 17.39 & 16.69 \\
\hline $\mathrm{FeO}$ & 20.05 & 26.00 & 22.45 & 22.99 & 19.92 \\
\hline $\mathrm{MnO}$ & 0.13 & 0.44 & 0.00 & 0.00 & 0.08 \\
\hline $\mathrm{MgO}$ & 20.64 & 17.84 & 19.13 & 19.46 & 19.18 \\
\hline $\mathrm{CaO}$ & 0.20 & 0.10 & 0.14 & 0.04 & 0.20 \\
\hline $\mathrm{Na}_{2} \mathrm{O}$ & 0.30 & 0.26 & 0.00 & 0.00 & 0.00 \\
\hline $\mathrm{K}_{2} \mathrm{O}$ & 0.07 & 0.06 & 0.00 & 0.00 & 0.02 \\
\hline Total & 87.78 & 90.73 & 90.65 & 89.65 & 85.42 \\
\hline $\mathrm{Si}$ & 5.80 & 5.28 & 6.19 & 6.05 & 6,20 \\
\hline $\mathrm{Ti}$ & 0.00 & 0.02 & 0.00 & 0.00 & 0.00 \\
\hline Al & 4.31 & 4.72 & 4.29 & 4.16 & 4.16 \\
\hline $\mathrm{Fe}$ & 3.41 & 4.39 & 3.77 & 3.90 & 3.52 \\
\hline $\mathrm{Mn}$ & 0.02 & 0.08 & 0.00 & 0.00 & 0.01 \\
\hline $\mathrm{Mg}$ & 6.27 & 5.38 & 5.72 & 5.89 & 6.05 \\
\hline $\mathrm{Ca}$ & 0.04 & 0.02 & 0.03 & 0.01 & 0.05 \\
\hline $\mathrm{Na}$ & 0.12 & 0.10 & 0.00 & 0.00 & 0.00 \\
\hline K & 0.02 & 0.02 & 0.00 & 0.00 & 0.01 \\
\hline $\mathrm{X}(\mathrm{Mg})$ & 0.66 & 0.59 & 0.56 & 0.59 & 0.60 \\
\hline Analysis no.: & 11 & 12 & 13 & 14 & 15 \\
\hline $\mathrm{SiO}_{2}$ & 28.53 & 30.91 & 30.40 & 29.28 & 29.73 \\
\hline $\mathrm{TiO}_{2}$ & 0.00 & 0.00 & 0.00 & 0.26 & 0.00 \\
\hline $\mathrm{Al}_{2} \mathrm{O}_{3}$ & 18.54 & 18.05 & 19.94 & 18.94 & 17.67 \\
\hline $\mathrm{FeO}$ & 23.98 & 20.94 & 22.79 & 22.66 & 18.24 \\
\hline $\mathrm{MnO}$ & 0.10 & 0.03 & 0.08 & 0.26 & 0.00 \\
\hline $\mathrm{MgO}$ & 15.09 & 18.59 & 20.51 & 18.97 & 21.69 \\
\hline $\mathrm{CaO}$ & 0.42 & 0.11 & 0.18 & 0.06 & 0.01 \\
\hline $\mathrm{Na}_{2} \mathrm{O}$ & 0.00 & 0.34 & 0.26 & 0.00 & 0.00 \\
\hline $\mathrm{K}_{2} \mathrm{O}$ & 0.10 & 0.00 & 0.00 & & 0.00 \\
\hline Total & 86.76 & 88.97 & 94.16 & 90.43 & 87.34 \\
\hline Si & 6.10 & 6.30 & 5.83 & 5.90 & 6.06 \\
\hline $\mathrm{Ti}$ & 0.00 & 0.00 & 0.00 & 0.04 & 0.00 \\
\hline Al & 4.67 & 4.33 & 4.51 & 4.50 & 4.24 \\
\hline $\mathrm{Fe}$ & 4.28 & 3.56 & 3.65 & 3.81 & 3.10 \\
\hline $\mathrm{Mn}$ & 0.02 & 0.01 & 0.01 & 0.04 & 0.00 \\
\hline $\mathrm{Mg}$ & 4.81 & 5.64 & 5.86 & 5.69 & 6.59 \\
\hline $\mathrm{Ca}$ & 0.10 & 0.02 & 0.04 & 0.01 & 0.00 \\
\hline $\mathrm{Na}$ & 0.00 & 0.13 & 0.10 & 0.00 & 0.00 \\
\hline K & 0.03 & 0.00 & 0.00 & 0.00 & 0.00 \\
\hline $\mathrm{X}(\mathrm{Mg})$ & 0.48 & 0.56 & 0.61 & 0.57 & 0.65 \\
\hline
\end{tabular}

Note: Major and minor elements measured in weight percent (wt \%). Analyses $1-3=$ Sample 137-504B-173R-2, 14-16 cm (Piece 2). Analysis $4=$ Sample 137-504B177R-1, I-3 cm (Piece 4). Analyses 5, 6 = Sample 140-504B-222R-1, 19-21 cm (Piece IF), Analysis 7 = Sample 140-504B-216R-1,3-5 cm (Piece 1). Analyses 8.9 $=$ Sample 140-504B-186R-1. $103-105 \mathrm{~cm}$ (Piece 14B). Analysis $10=$ Sample 140504B-198R-1, 70-71 cm (Piece 18). Analysis II = Sample 140-504B-208R-1, 85$87 \mathrm{~cm}$ (Piece 19A). Analyses 12, $13=$ Sample 137-504B-177R-1, 1-3 cm (Piece 1). Analysis $14=$ Sample 140-504B-217R-1, 0-2 cm (Piece 1). Analysis $15=$ Sample 140-504B-237R-1, 1-3 cm (Piece I). 


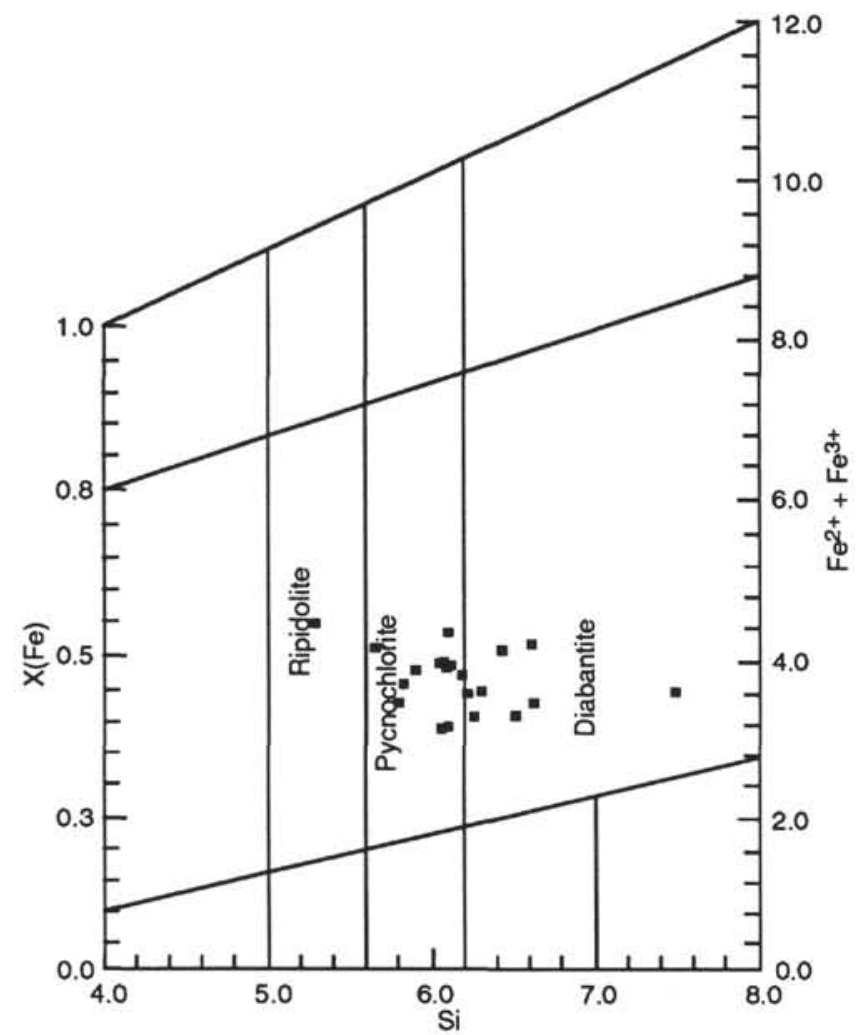

Figure 8. Composition of chlorite from 15 samples from Hole 504B cores recovered during Legs 137 and 140 .

Table 8. Electron microprobe analysis of anhydrite from a vein.

\begin{tabular}{lr}
\hline Analysis no.: & \multicolumn{1}{c}{1} \\
\hline $\mathrm{Al}_{2} \mathrm{O}_{3}$ & 0.06 \\
$\mathrm{FeO}$ & 0.00 \\
$\mathrm{MnO}$ & 0.00 \\
$\mathrm{MgO}$ & 0.10 \\
$\mathrm{CaO}$ & 43.77 \\
$\mathrm{Na} \mathrm{Na}_{2} \mathrm{O}$ & 0.20 \\
$\mathrm{~K}_{2} \mathrm{O}$ & \\
$\mathrm{SO}_{3}$ & 56.30 \\
Total & 100.43 \\
$\mathrm{Ca}$ & 1.04 \\
$\mathrm{Na}$ & 0.01 \\
$\mathrm{~S}$ & 0.94 \\
\hline
\end{tabular}

Note: Major and minor elements measured in weight percent $(\mathrm{wt} \%)$. Analysis $1=$ Sample 140-504B-217R-1, 0-2 cm (Piece 1).

The assemblage chlorite + amphibole (with or without albite, quartz, titanite or ilmenite) is specific for groups 1 and 2 of alteration. The best temperature indicator for these groups is amphibole composition, which in our study is actinolite, actinolitic hornblende, or magnesian hornblende. In the marginal $\mathrm{Fe}$-free system hornblende first appears by the reaction

$$
\mathrm{Zo}+\mathrm{Chl}+\mathrm{Tr}+\mathrm{Qtz}=\mathrm{Hbl}+\mathrm{H}_{2} \mathrm{O},
$$

at $\mathrm{T}=350^{\circ}-410^{\circ} \mathrm{C}$, and $\mathrm{Fe}$ addition shifts the equilibrium toward slightly higher temperatures (Liou et al., 1985; $\mathrm{Zo}=$ zoisite, $\mathrm{Chl}=$ chlorite, $\mathrm{Tr}=$ tremolite, $\mathrm{Qtz}=$ quartz, and $\mathrm{Hbl}=$ hornblende). The first appearance of chlorite-actinolite assemblages at the noted low pressures takes place at about $350^{\circ} \mathrm{C}$ by prehnite breakdown:
Table 9. Electron microprobe analysis of epidote from a vein.

\begin{tabular}{lc}
\hline Analysis no.: & 1 \\
\hline $\mathrm{SiO}_{2}$ & 39 \\
$\mathrm{TiO}_{2}$ & 0.13 \\
$\mathrm{Al}_{2} \mathrm{O}_{3}$ & 25 \\
$\mathrm{Fe}_{2} \mathrm{O}_{3}$ & 6.73 \\
$\mathrm{MnO}$ & 0.22 \\
$\mathrm{MgO}$ & 2.75 \\
$\mathrm{CaO}$ & 22.59 \\
$\mathrm{Na} \mathrm{O}_{2} \mathrm{O}$ & 0 \\
$\mathrm{~K}_{2} \mathrm{O}$ & 0 \\
$\mathrm{Total}^{2}$ & 96.48 \\
$\mathrm{Si}$ & 3.06 \\
$\mathrm{Ti}$ & 0.01 \\
$\mathrm{Al}$ & 2.31 \\
$\mathrm{Fe}$ & 0.39 \\
$\mathrm{Fe}$ & 0.00 \\
$\mathrm{Mn}$ & 0.01 \\
$\mathrm{Mg}$ & 0.32 \\
$\mathrm{Ca}$ & 1.90 \\
$\mathrm{Na}$ & 0.00 \\
$\mathrm{~K}$ & 0.00 \\
$\mathrm{X}(\mathrm{Fe})$ & 0.14 \\
$\mathrm{X}(\mathrm{Mn})$ & 0.01 \\
\hline
\end{tabular}

Note: Major and minor elements measured in weight percent (wt $\%$ ). Analysis I = Sample 140-504B-216R-1, 3-5 cm (Piece 1),

Table 10. Electron microprobe analyses of talc and smectite from pseudomorphs after olivine phenocrysts.

\begin{tabular}{|c|c|c|c|c|c|}
\hline Analysis no.: & 1 & 2 & 3 & 4 & 5 \\
\hline $\mathrm{SiO}_{2}$ & 62.82 & 57.99 & 57.90 & 58.18 & 53.30 \\
\hline $\mathrm{TiO}_{2}^{-}$ & 0.00 & 0.00 & 0.00 & 0.00 & 0.00 \\
\hline $\mathrm{Al}_{2} \overline{\mathrm{O}}_{3}$ & 0.40 & 0.00 & 1.42 & 1.44 & 1.68 \\
\hline $\mathrm{FeO}$ & 1.36 & 5.21 & 5.87 & 5.93 & 6.25 \\
\hline $\mathrm{MnO}$ & 0.00 & 0.05 & ND & ND & 0.00 \\
\hline $\mathrm{MgO}$ & 30.21 & 30.32 & 27.47 & 28.95 & 25.30 \\
\hline $\mathrm{CaO}$ & 0.00 & 0.31 & 0.31 & 0.39 & 0.60 \\
\hline $\mathrm{Na}_{2} \mathrm{O}$ & 0.08 & 0.00 & ND & ND & 0.00 \\
\hline Total & 0.08 & 0.00 & ND & ND & 0.00 \\
\hline Si & 8.03 & 7.53 & 7.67 & 7.52 & 6.47 \\
\hline $\mathrm{Ti}$ & 0.00 & 0.00 & 0.00 & 0.00 & 0.00 \\
\hline Al & 0.06 & 0.00 & 0.22 & 0.22 & 0.24 \\
\hline $\mathrm{Fe}$ & 0.15 & 0.57 & 0.20 & 0.64 & 0.63 \\
\hline $\mathrm{Mn}$ & 0.00 & 0.01 & 0.00 & 0.00 & 0.00 \\
\hline $\mathrm{Mg}$ & 5.75 & 5.86 & 5.42 & 5.57 & 4.58 \\
\hline $\mathrm{Ca}$ & 0.00 & 0.04 & 0.04 & 0.05 & 0.08 \\
\hline $\mathrm{Na}$ & 0.02 & 0.00 & 0.00 & 0.00 & 0.00 \\
\hline
\end{tabular}

Notes: Major and minor elements measured in weight percent (wt\%). Analyses $1=$ Sample 140-504B-204R-1, 23-27 cm (Piece 4). Analyses 2-4 = Sample 140-504B200R-I, 28-30 cm (Piece 6). Analysis $5=$ Sample 140-504B-204R-1, 23-27 cm (Piece 4). Analyses $1-4$ are from talc, and Analysis 5 is from smectite. ND $=$ not determined.

Table 11. Electron microprobe analyses of secondary titanite from groundmass.

\begin{tabular}{lrr}
\hline Analysis no.: & \multicolumn{1}{c}{1} & \multicolumn{1}{c}{2} \\
\hline $\mathrm{SiO}_{2}$ & 31.21 & 31.10 \\
$\mathrm{TiO}_{2}$ & 35.73 & 36.41 \\
$\mathrm{Al}_{2} \mathrm{O}_{3}$ & 2.00 & 1.81 \\
$\mathrm{FeO}$ & 2.70 & 1.44 \\
$\mathrm{MgO}$ & 0.07 & 0.10 \\
$\mathrm{CaO}$ & 27.50 & 27.60 \\
$\mathrm{Na} 2$ & 0.66 & 0.59 \\
$\mathrm{Total}$ & 99.87 & 99.05 \\
$\mathrm{Si}$ & 1.00 & 1.01 \\
$\mathrm{Ti}$ & 0.86 & 0.89 \\
$\mathrm{Al}$ & 0.08 & 0.07 \\
$\mathrm{Fe}$ & 0.07 & 0.02 \\
$\mathrm{Mg}$ & 0.00 & 0.00 \\
$\mathrm{Ca}$ & 0.94 & 0.96 \\
$\mathrm{Na}$ & 0.04 & 0.04 \\
\hline
\end{tabular}

Note: Major and minor elements measured in weight percent (wt\%). Analyses I, 2 = Sample 140-504B-217R-1, 0-2 cm (Piece I). 


$$
\mathrm{Prh}+\mathrm{Chl}+\mathrm{Qtz}=\mathrm{Czo}+\mathrm{Tr}+\mathrm{H}_{2} \mathrm{O},
$$

where $\operatorname{Prh}=$ prehnite and $\mathrm{Czo}=$ clinozoisite. Thus, type 1 and 2 alterations occurred over the temperature range of $350^{\circ}-450^{\circ} \mathrm{C}$.

The following equilibria apply for the assemblage prehnite + anhydrite + epidote (alteration group 3 ):

1. Appearance of a prehnite-zoisite assemblage at $\mathrm{T}=200^{\circ}-$ $230^{\circ} \mathrm{C}$ upon the disappearance of zeolites from the following reactions:

$$
\mathrm{Lm}+\mathrm{Pr}=\mathrm{Zo}+\mathrm{Qtz}+\mathrm{H}_{2} \mathrm{O},
$$

and

$$
\mathrm{Lw}+\mathrm{Pr}=\mathrm{Zo}+\mathrm{H}_{2} \mathrm{O}
$$

where Lw = lawsonite.

2. Breakdown of this assemblage upon prehnite disappearance at $\mathrm{T}=330^{\circ} 350^{\circ} \mathrm{C}$ (Liou et al., 198) from the following reaction:

$$
\mathrm{Prh}+\mathrm{Chl}+\mathrm{Qtz}=\mathrm{Zo}+\mathrm{Tr}+\mathrm{H}_{2} \mathrm{O}
$$

Zeolite-clay alterations are the most low-temperature of those investigated. We did not study zeolites from our samples, but zeolites in similar rocks are represented by laumontite and stilbite (Alt et al., 1985; Ishizuka, 1989). The equilibrium Stil = Lm + Qtz takes place at a temperature of about $150^{\circ} \mathrm{C}$, and at about $250^{\circ} \mathrm{C}$ (Liou et al., 1985), which we accept as the stability limit for that assemblage, laumontite breaks down:

$$
\mathrm{Lm}=\mathrm{Wr}+\mathrm{Qtz}
$$

where $\mathrm{Lm}=$ laumontite and $\mathrm{Wr}=$ wairakite.

The formation of complex pseudomorphs after olivine phenocrysts represents a rather specific case, for these pseudomorphs commonly contrast conspicuously against the moderately altered diabase groundmass. This fact suggests an independence of the origin of these pseudomorphs on other mineral reactions within the rock, ranging from the rather high-temperature ones ( $\mathrm{Ca}$-free amphibole formation) down to low-temperature reactions (smectite and zeolite appearance in the post-dike period). The olivine pseudomorphs preserve, in spite of $\mathrm{MgO}$ and $\mathrm{H}_{2} \mathrm{O}$ opposing transportation, high $\mathrm{MgO}$ and low $\mathrm{CaO}$ and $\mathrm{Al}_{2} \mathrm{O}_{3}$ activities. So, sometimes low oxygen activities, corresponding to the Fe-talc occurrence within such pseudomorphs, contrast conspicuously against rather oxidative conditions observed elsewhere (judging from magnetite or even hematite inclusions within talc grains). Mineralogically different pseudomorphs after olivine could occur even within one thin section. Still another possibility is a difference in relative ages of the "reduction" and "oxidation" pseudomorphs (and corresponding conditions).

\section{SUMMARY}

Both changes in time-temperature and oxidation-reduction conditions, in general, control the appearance of one or another mineral type of alteration. During the time of dike intrusion, probably an interval of tens to hundred of thousands of years, the temperature is approximately constant at about $350^{\circ}-400^{\circ} \mathrm{C}$ because of the frequent intrusions of new dikes. The inevitable spatial and temporal fluctuations of temperature are responsible for the distribution of alteration types. Oxidative alteration (anhydrite, prehnite, epidote assemblage) appears to be associated with the relatively younger dikes, possibly forming zones permeable to seawater for a short time. Clay minerals and zeolites appear in post-dike modern time, in dikes cooled down to $200^{\circ} \mathrm{C}$ or less.

The conditions for the assemblages chlorite-amphibole-titanite and chlorite-amphibole-ilmenite appear to differ in that the temperature of formation of the latter is slightly higher. The temperature increase indicates a decrease of $\mathrm{CaO}$ chemical activity.

The appearance of metasomatic veins and patches with halos among the time sequence of veins of filling suggests that the temporal temperature fluctuations induced fluid pressure difference between pores and fractures possibly caused by the formation of convective hydrothermal cells of smaller orders.

In the alteration process, olivine phenocrysts are sufficiently isolated from the matrix and seem to represent metastable individual physicochemical systems with a specific regime of alteration conditions.

\section{ACKNOWLEDGMENTS}

The authors are grateful to ODP for providing the samples for this work. We thank the reviewers, Dr. Debra S. Stakes, Dr. H.B.J. Dick, Dr. J.C. Alt, and an anonymous reviewer, for their attention and fruitful criticism, which made possible improvement of the manuscript. Especial gratitude is owed to Jennifer Marin, whose attention to the manuscript allowed us to improve the English. Dr. Laura Stokking was of great help during the preparation of the manuscript. We also thank her for her important comments and constructive criticism, which we considered in the final version of the paper. Of great help to us was O.V. Polozova (IGEM RAS), who performed most of the microprobe analyses. The work was conducted under the financial support of The World Ocean Russian State Scientific Program.

\section{REFERENCES}

Adamson, A.C., 1983. Chemistry of alteration minerals from Deep Sea Drilling Project Sites 501, 504, and 505. In Cann, J.R., Langseth, M.J., Honnorez, J., Von Herzen, R.P., White, S.M., et al., Init. Repts. DSDP, 69: Washington (U.S. Govt. Printing Office), 551-563.

Alt, J.C., Honnorez, J., Hubberten, H.-W., and Saltzman, E., 1983. Occurrence and origin of anhydrite from Deep Sea Drilling Project Leg 70, Hole 504B, Costa Rica Rift. In Cann, J.R., Langseth, M.G., Honnorez, J.. Von Herzen, R.P., White, S.M., et al., Init. Repts. DSDP, 69: Washington (U.S. Govt. Printing Office), 547-550.

Alt, J.C., Honnorez, J., Laverne, C., and Emmermann, R., 1986. Hydrothermal alteration of a $1 \mathrm{~km}$ section through the upper oceanic crust, Deep Sea Drilling Project Hole 504B: mineralogy, chemistry and evolution of basalt-seawater interactions. J. Geophys. Res., 91:10309-10335.

Alt, J.C., Laverne, C., and Muehlenbachs, K., 1985. Alteration of the upper oceanic crust: mineralogy and processes in Deep Sea Drilling Project Hole 504B, Leg 83. In Anderson, R.N., Honnorez, J., Becker, K., et al., Init. Repts. DSDP, 83: Washington (U.S. Govt. Printing Office), 217247.

Bass, M.N., 1976. Secondary minerals in oceanic basalt, with special reference to Leg 34, Deep Sea Drilling Project. In Yeats, R.S., Hart, S.R., et al., Init. Repts. DSDP, 34: Washington (U.S. Govt. Printing Office), $393-$ 432.

Bohlke, J.K., Honnorez, J., and Honnorez-Guerstein, B.M., 1980. Alteration of basalts from Site 396B, DSDP: petrographic and mineralogic studies. Contrib. Mineral. Petrol., 73:341-364.

Dick, H.J.B., Erzinger, J., Stokking, L.B., et al., 1992. Proc. ODP, Init. Repts., 140: College Station, TX (Ocean Drilling Program).

Hart, R.A., 1973. A model for chemical exchange in the basalt-seawater system of oceanic Layer 2. Can. J. Earth Sci., 10:799-816.

Honnorez, J., Bohlke, J.L., and Honnorez-Guerstein, B.M., 1978. Petrographical and geochemical study of the low temperature submarine alteration of basalt from Hole 396B, Leg 46. In Dmitriev, L., Heirtzler, J., et al., Init. Repts. DSDP, 46: Washington (U.S. Govt. Printing Office), 299_ 330.

Honnorez, J., Laverne, C., Hubberten, H.-W., Emmermann, R., and Muehlenbachs, K., 1983. Alteration processes in layer 2 basalts from Deep Sea Drilling Project Hole 504B, Costa Rica Rift. In Cann, J.R., Langseth, 
M.G., Honnorez, J., Von Herzen, R.P., White, S.M., et al., Init. Repts. DSDP, 69: Washington (U.S. Govt. Printing Office), 509-542.

Ishizuka, H., 1989. Mineral paragenesis of altered basalts from Hole 504B, ODP Leg 111. In Becker, K., Sakai, H., et al., Proc. ODP, Sci. Results, 111: College Station, TX (Ocean Drilling Program), 61-76.

Kelley, D.S., and Gillis, K.M., 1993. Fluid evolution in submarine magmahydrothermal systems at the Mid-Atlantic Ridge. J. Geophys. Res., 98: 19579-19596.

Korzhinskii, D.S., 1970. Theory of Metasomatic Zoning: Oxford (Clarendon Press).

Kurnosov, V.B., Kholodkevich, I.V., and Chubarov, V.M., 1983. Secondary minerals in basalt from the Costa Rica Rift, Holes 501 and 504B, Deep Sea Drilling Project Legs 68, 69, and 70. In Cann, J.R., Langseth, M.G.. Honnorez, J., Von Herzen, R.P., White, S.M., et. al., Init. Repts. DSDP, 69: Washington (U.S. Govt. Printing Office), 573-584.

Laverne, C., 1983. Occurrence of melanite and aegirine-augite in Deep Sea Drilling Project Hole 504B. In Cann, J.R., Langseth, M.G., Honnorez, J., Von Herzen, R.P., White, S.M., et al., Init. Repts. DSDP, 69: Washington (U.S. Govt. Printing Office), 593-605.

Leake, B.E., 1978. Nomenclature of amphiboles. Am. Mineral., 63:10231052.

Liou, J.G., Maruyama, S., and Cho, M., 1985. Phase equilibria and mineral parageneses of metabasites in low-grade metamorphism. Mineral. Mag., 49:321-333.

Mével, C., 1980. Mineralogy and chemistry of secondary phases in low temperature altered basalts from Deep Sea Drilling Project Legs 51, 52, and 53. In Donnelly, T., Francheteau, J., Bryan, W., Robinson, P., Flower, M., Salisbury, M., et al., Init. Repts. DSDP, 51, 52, 53 (Pt. 2): Washington (U.S. Govt. Printing Office), 1299-1318.

Noack, Y., Emmermann, R., and Hubberten, H.-W., 1983. Alteration in Site 501 (Leg 68) and Site 504 (Leg 69) basalts: preliminary results. In Cann,
J.R., Langseth, M.G., Honnorez, J., Von Herzen, R.P., White, S.M., et al., Init. Repts. DSDP, 69: Washington (U.S. Govt. Printing Office), $497-$ 508 .

Pertsev, N.N., and Boronikhin, V.A., 1983a. Alteration zones near veins in basalts from Deep Sea Drilling Project Sites 501/504 and 505, Costa Rica Rift. In Cann, J.R., Langseth, M.G., Honnorez, J., Von Herzen, R.P., White, S.M., et al., Init. Repts. DSDP, 69: Washington (U.S. Govt. Printing Office), 565-572.

1983b. Secondary K-feldspar in basalts at Deep Sea Drilling Project Hole 504B and the problem of K-feldspathization in oceanic basalts. In Cann, J.R., Langseth, M.G., Honnorez, J., Von Herzen, R.P., White, S.M., et al., Init. Repts. DSDP, 69: Washington (U.S. Govt. Printing Office), 589-591.

Pertsev, N.N., and Rusinov, V.L., 1980. Mineral assemblages and processes of alteration in basalts at Deep Sea Drilling Project Sites 417 and 418. In Donnelly, T., Francheteau, J., Bryan, W., Robinson, P., Flower, M., Salisbury, M., et al., Init. Repts. DSDP, 51, 52, 53 (Pt. 2): Washington (U.S. Govt. Printing Office), 1219-1242.

Zoback, M.D., and Anderson, R.N., 1983. Permeability, underpressures, and convection in the oceanic crust Deep Sea Drilling Project Hole 504B. In Cann, J.R., Langseth, M.G., Honnorez, J., Von Herzen, R.P., White, S.M., et al., Init. Repts. DSDP, 69: Washington (U.S. Govt. Printing Office), 245-254.

Date of initial receipt: 23 March 1993

Date of acceptance: 17 January 1995

Ms 148SR-158 